\title{
A review of the environmental safety of the Cry1Ac protein
}

\section{Center for Environmental Risk Assessment, ILSI Research Foundation}

1156 Fifteenth Street N.W., Washington DC 20005-1743, USA

May 26, 2010

Keywords: Cry1Ac / Bacillus thuringiensis / insect resistance / genetically engineered / environmental risk assessment

\section{INTRODUCTION}

This document provides a comprehensive review of information and data relevant to the environmental risk assessment of Cry1Ac and presents a summary statement about the environmental safety of this protein. All sources of information reviewed herein were publically available and included: dossiers presented to regulatory authorities; decision summaries prepared by regulatory authorities; peer reviewed literature; and product summaries prepared by product developers.

Environmental risk assessments related to the introduction of genetically engineered (GE) plants are conducted on a case-by-case basis taking into account the biology of the plant, the nature of the transgene and the protein it produces, the phenotype conferred by the transgene as well as the intended use of the plant and the environment where it will be introduced (i.e., the receiving environment). These assessments are comparative by necessity, and typically involve comparisons to an untransformed parent line or closely related isoline $(\mathrm{CBD}$, 2000a, 2000b; Codex, 2003a, 2003b; EFSA, 2006; NRC, 1989; OECD, 1992). The point of these comparisons is to identify potential risks the GE plant might present beyond what is already accepted for like plants in the environment. Any identified risks can then be assessed for likelihood and potential consequence.

Regulatory approvals for environmental release of GE plants expressing Cry1Ac have been issued in eleven countries and include three species of plants (CERA, 2010; CFIA, 1997; CTNBio, 2005; Japan BCH, 1997, 1999, 2007; OGTR, 2002b, 2003a, 2003c, 2006a, 2006c; USDA APHIS, 1995, 1997a, 1997d, 2001, 2004) (Tab. 1).
One event ${ }^{1}$ each for maize (Zea mays) and tomato

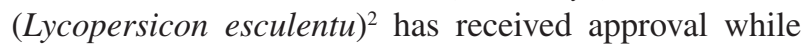
12 lines of cotton ${ }^{3}$ (Gossypium hirsutum) have received approval in at least one country. These regulatory reviews have generally considered the potential for Cry1Ac to adversely affect non-target organisms, the potential for Cry1Ac expression to affect the weediness potential of the modified plant, and the potential for gene flow to impact the weediness of wild relatives (CFIA, 1997; CTNBio, 2005; Japan BCH, 1997, 1999, 2007; OGTR, 2002b, 2003a, 2003c, 2006a, 2006c; USDA APHIS, 1995, 1997a, 1997d, 2001, 2004).

\section{ORIGIN AND FUNCTION OF CRY1AC}

\section{Bacillus thuringiensis and the $\operatorname{Cry} \delta$-endotoxins}

Bacillus thuringiensis is a rod-shaped, gram positive bacterium capable of forming long-lived endospores. It is often referred to as a soil bacterium although it is ubiquitous in the environment (Hofte and Whiteley, 1989;

\footnotetext{
${ }^{1}$ Event refers to a single transformation event: the incorporation of a transgene into a plant genome. A single transformation event can be crossed into multiple lines.

2 Tomato Event 5345 expressing Cry1Ac was deregulated by USDA APHIS but never received registration as a pesticide with the USEPA and was not commercialized anywhere in the world. It will not be considered elsewhere in this paper.

3 This includes approvals for lines generated through breeding and transformation with additional transgenes.
} 
Table 1. Regulatory approvals for the environmental release of GE plants containing Cry1Ac.

\begin{tabular}{|c|c|c|c|c|c|c|c|c|c|c|c|c|c|}
\hline Species & Event Name & Also Known As & 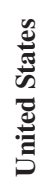 & 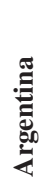 & & 胥 & 离 & 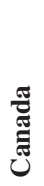 & $\frac{\frac{\pi}{0}}{\text { है }}$ & 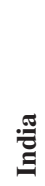 & 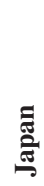 & 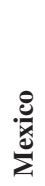 & 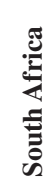 \\
\hline \multirow[t]{12}{*}{$\begin{array}{l}\text { Gossypium hirsutum } \\
\text { (cotton) }\end{array}$} & MON-15985-7 & MON 15985 & $\mathrm{X}$ & & $\mathrm{X}$ & $\mathrm{X}$ & $\mathrm{X}$ & & & $\mathrm{X}$ & & & $\mathrm{X}$ \\
\hline & DAS-21023-5 & $3006-210-23$ & $\mathrm{X}$ & & & & & & & & & & \\
\hline & $31807 / 31808$ & & $\mathrm{X}$ & & & & & & & & $\mathrm{X}$ & & \\
\hline & DAS-21023-5 x DAS-24236-5 & & $\mathrm{X}$ & & & $\mathrm{X}$ & & & & & & & \\
\hline & DAS-21023-5 x DAS-24236-5 $x$ & $\mathrm{~N}-01445-2$ & $*$ & & & & & & & & & & \\
\hline & DAS-21023-5 x DAS-24236-5 x & N88913 & $*$ & & & & & & & & & & \\
\hline & Event-1 & & & & & & & & & $\mathrm{X}$ & & & \\
\hline & ACS-GH001-3, MON-15985-7 & $\begin{array}{l}\text { LLCotton25 x } \\
\text { MON15985 }\end{array}$ & * & & & & & & & & $\mathrm{X}$ & & \\
\hline & MON-15985-7 x MON-01445-2 & & $*$ & & $\mathrm{X}$ & & & & & & & & \\
\hline & MON-00531-6 x MON-01445-2 & & $*$ & $X$ & $\mathrm{X}$ & $X$ & & & & & & & $\mathrm{X}$ \\
\hline & MON-15985-7, MON-88913-8 & $\begin{array}{l}\text { MON15985 x } \\
\text { MON88913 }\end{array}$ & * & & $\mathrm{X}$ & & & & & & & & $\mathrm{X}$ \\
\hline & MON-00531-6, MON-00757-7 & MON531/757/1076 & $\mathrm{X}$ & $\mathrm{X}$ & $\mathrm{X}$ & $\mathrm{X}$ & & & $\mathrm{X}$ & $\mathrm{X}$ & $\mathrm{X}$ & $\mathrm{X}$ & $\mathrm{X}$ \\
\hline $\begin{array}{l}\text { Lycopersicon } \\
\text { esculentum (tomato) }\end{array}$ & 5345 & & $\mathrm{X}$ & & & & & & & & & & \\
\hline Zea mays (maize) & DKB-89614-9 & DBT418 & $\mathrm{X}$ & $\mathrm{X}$ & & & & $\mathrm{X}$ & & & $\mathrm{X}$ & & \\
\hline
\end{tabular}

$\mathrm{X}$ indicates a regulatory approval.

*Stacked events that may be considered approved for environmental release based on existing approvals for the GE parent lines from which they are derived. Approvals are dependent on pesticide registrations which require period renewal.

Schnepf et al., 1998; OECD, 2007). There is tremendous variation within the species with regard to production of a range of pesticidal proteins that differ in mode of action, target specificity and mechanism of expression (Hofte and Whiteley, 1989; Schnepf et al., 1998; OECD, 2007). Pesticidal proteins expressed by $B$. thuringiensis strains include antifungal compounds, $\beta$ exotoxins ${ }^{4}$, vegetative insecticidal protein (Vip), and the $\delta$ endotoxins which include the Cry (crystalline) proteins and the structurally unrelated Cyt (cytolytic) proteins (Hofte and Whiteley, 1989; Schnepf et al., 1998; OECD, 2007). Most of these have been shown to contribute to insect toxicity and some (notably $\beta$ exotoxins and Cyt proteins) are widely toxic (Hofte and Whiteley, 1989; Schnepf et al., 1998; OECD, 2007).

Preparations of natural isolates of $B$. thuringiensis were first used as a commercial insecticide in France in 1938 and B. thuringiensis subspecies kurstaki (which produces Cry1Ac among other Cry proteins) has been registered with US EPA since 1961 (Kumar et al., 1996; Schnepf et al., 1998; USEPA, 2001). Microbial preparations of

\footnotetext{
${ }^{4}$ also called thuringiensin
}

B. thuringiensis are currently approved for use around the world including in Australia, Canada, the European Union, and the United States (AVPMA, 2010; EU DG SANCO, 2010; PMRA, 2008; USEPA, 2001). These preparations contain a mixture of microbial pesticides including Cry proteins that interact extensively with each other to influence toxicity and insect specificity (Schnepf et al., 1998; OECD, 2007). Although it may be possible to extrapolate some information about the environmental safety of Cry proteins from experience with these bacterial preparations, it should be kept in mind that the activity of bacterial foliar sprays is due to a combination of multiple $\delta$ endotoxins as well as other toxins and qualities of the spore itself that can have an impact on selectivity and host range (Schnepf et al., 1998; Tabashnik et al., 1992). Similarly, the exposure profile for foliar sprays of bacterial preparations differs from expression of Cry proteins in a GE plant (OECD, 2007).

The Cry protein $\delta$ endotoxins are so named because they are the primary component of the protein parasporal crystals that are characteristic of spore formation in $B$. thuringiensis (Hofte and Whiteley, 1989; Kumar et al., 1996; Schnepf et al., 1998; OECD, 2007). A systematic nomenclature for identifying and differentiating Cry 
proteins was proposed in 1989 and widely adopted (Hofte and Whiteley, 1989; OECD, 2007). This system has been subsequently updated to account for additional Cry proteins and expanding knowledge of their molecular function and relatedness, leading to some minor discrepancies in naming with earlier literature (Crickmore et al., 1998; Crickmore et al., 2005; OECD, 2007). This document uses the most recent nomenclature (Cry1Ac for the protein, crylAc for the gene) but the protein in question is synonymous with the older nomenclature CryIA(c).

All of the Cry1 proteins are closely related based on sequence and the proteins designated Cry1A (including $\mathrm{Cy} 1 \mathrm{Aa}, \mathrm{Cry} 1 \mathrm{Ab}$ and Cry1Ac) are greater than $85 \%$ identical in amino acid sequence (Crickmore et al., 1998). The crystal structure of Cry1Aa has been determined and shows a high degree of structural similarity to other known Cry protein structures (Cry3A, Cry2A, Cry4A, and Cry4B) despite sequence identities that can fall below $30 \%$ (Aronson and Shai, 2001; Bravo et al., 2007; Crickmore etal., 1998; Kumaretal., 1996;OECD, 2007).In theoriginal nomenclature, the Cry proteins were designated based on their insecticidal activity (CryI proteins were those active against lepidopterans), and although the nomenclature is now sequence dependent the target specificity remains largely intact such that proteins designated Cry1 have activity specifically against lepidopterans (Aronson and Shai, 2001; Crickmore et al., 1998; Hofte and Whiteley, 1989; Kumar et al., 1996; OECD, 2007).

\section{Mechanism of Cry1Ac insecticidal activity}

Although there is significant variability in amino acid sequence and target range, the general mechanism by which Cry proteins (including Cry1Ac) achieve insecticidal activity is believed to be common across the group (Aronson and Shai, 2001; Bravo et al., 2007; Crickmore et al., 1998, 2005; Hofte and Whiteley, 1989; Kumar et al., 1996; OECD, 2007). The Cry1 proteins are produced in the form of protoxins of 130-140 kDa in size containing 1100-1200 amino acid residues (Aronson and Shai, 2001; Bravo et al., 2007; Kumar et al., 1996; OECD, 2007). For Cry $1 \mathrm{~A}$ these protoxins are cleaved to generate active toxins consisting of 60-70 $\mathrm{kDa}$ fragments from the $\mathrm{N}$ terminal portion of the protein (Knowles, 1994; Kumar et al., 1996). These so-called active toxins bind to specific receptors on the plasma membrane of midgut epithelium cells in susceptible insects (Aronson and Shai, 2001; Bravo et al., 2007; Kumar et al., 1996; OECD, 2007). Once bound to receptors, the toxin is able to insert into the plasma membrane and form oligomeric transmembrane pores (Aronson and Shai, 2001; Bravo et al., 2007;
Kumar et al., 1996; OECD, 2007). It is believed that these pores form ion channels that disrupt the transmembrane potential, causing osmotic lysis (Aronson and Shai, 2001; Hofte and Whiteley, 1989; Kumar et al., 1996; OECD, 2007). The biochemical process of membrane insertion is not completely understood. There is evidence that some Cry proteins have multiple receptors, or may bind to multiple sites on a single receptor and it has been demonstrated that receptor binding is necessary but not sufficient for toxicity (Aronson and Shai, 2001; Jenkins et al., 1999; OECD, 2007). There is some evidence based partly on experiments using sublethal concentrations, that there may be other relevant interactions between Cry proteins and their insect targets (Aronson and Shai, 2001; Zhang et al., 2006).

\section{EXPRESSION OF CRY1AC IN INSECT RESISTANT GE PLANTS}

The level of expression of Cry1Ac in GE plants is determined by several factors related to the types of promoter and terminating sequences and the gene insert site(s). Each transformation event therefore results in a different expression profile. Data for the level of expression of Cry1Ac in GE plants that have obtained regulatory approvals are available in publicly accessible regulatory submissions and decision documents (CFIA, 1996, 1997, 2004, 2005; CTNBio, 2005, 2009; OGTR, 2003, 2006; USDA APHIS, 1994, 1996, 1997a, 1997b, 2003, 2000; USEPA, 2001; USFDA, 1997). Tissue types and collection methods differed between studies but all used an enzyme-linked immunosorbent assay (ELISA) to quantify the amount of Cry1Ac protein present in a given sample.

Typically, one or more samples of plant tissue were taken at a field trial site and pooled for analysis. The amount of Cry1Ac was normally determined on a dry weight basis then calculated to provide environmentally relevant values relative to the total fresh weight of the sample and represented in a ratio (e.g., micrograms of Cry1Ac protein per gram of fresh weight) (CFIA, 1996, 1997, 2004, 2005; CTNBio, 2005, 2009; OGTR, 2003, 2006; USDA APHIS, 1994, 1996, 1997a, 1997b, 2003, 2000; USEPA, 2001; USFDA, 1997). Samples were usually collected from several tissue types and at multiple growth stages providing data from plants over time and from multiple locations. In most cases the data were presented as a mean value (normally a mean of means as values were averaged within a field trial and across trials as well) and a range (normally also a range of means representing the average expression at a trial 
Table 2. Highest reported protein concentrations of Cry1Ac in GE plant tissue.

\begin{tabular}{|l|l|l|l|l|}
\hline Species & Events & Tissue With Highest Expression & Range & Citation \\
\hline \multirow{5}{*}{ Gossypium hirsutum } & MON-15985-7 & Seed & $3.35 \pm 0.63^{1} \mu \mathrm{g} / \mathrm{g} \mathrm{FW}^{2}$ & OGTR, 2002 \\
\cline { 2 - 5 } & DAS-21023-5 & Young Leaf & $0.46-3.5 \mu \mathrm{g} / \mathrm{g}$ DW & USDA, $^{3}$ \\
\cline { 2 - 5 } & DAS-21023-5 X DAS-24236-5 & Flower & $1.83 \mu \mathrm{g} / \mathrm{g}$ DW & FSANZ, 2004 \\
\cline { 2 - 5 } & $31807 / 31808$ & Seed $^{4}$ & $2.5 \mu \mathrm{g} / \mathrm{g}$ FW & FDA, 1997 \\
\cline { 2 - 5 } & MON-00531-6 & Young Leaf & $5.00 \pm 1.84^{1} \mu \mathrm{g} / \mathrm{g}$ FW & OGTR, 2002 \\
\hline Zea mays & DKB-89614-9 & Harvest Leaf & $626.8 \pm 141.62^{5} \mathrm{ng} / \mathrm{g}$ FW & USDA, 1996 \\
\hline
\end{tabular}

${ }^{1}$ Standard Deviation

${ }^{2} \mathrm{FW}=$ fresh weight

${ }^{3} \mathrm{DW}=$ dry weight.

${ }^{4}$ Only tissue reported.

${ }^{5}$ Standard Error.

site, although this also varied depending on the individual example). In other data sets, means are provided with the standard deviation or the standard error of means. (CFIA, 1996, 1997, 2004, 2005; CTNBio, 2005, 2009; OGTR, 2003, 2006; USDA APHIS, 1994, 1996, 1997a, 1997b, 2003, 2000; USEPA, 2001; USFDA, 1997).

Variations in methodology for sample collection make direct statistical cross-comparisons of the data inappropriate but the weight of evidence suggests that GE plants expressed Cry1Ac at very low levels relative to the total protein available in the plant (see Annex I and references therein). Table 2 includes the highest reported values of expression in Cry1Ac expressing GE plants where data were available. Additional information about expression of Cry1Ac is contained in Annex I.

\section{NON-TARGET ORGANISM (NTO) TESTING AND IMPACTS OF EXPOSURE TO CRY1AC PROTEIN}

The Cry1Ac protein has insecticidal properties against certain lepidopteran insects when they feed on a substrate containing the Bt protein (Crickmore et al., 1998, 2005; Hofte and Whiteley, 1989; OECD, 2007). The objective of inserting the crylAc gene into a crop is to provide protection from feeding damage by such pests. Other organisms that are not pests in the agricultural system may also be exposed to the Cry1 Ac protein, and are considered "non-target organisms" (NTOs). Such exposure could be direct, from deliberate or incidental feeding on crop tissues such as pollen or decaying leaf material, or be indirect, from feeding on other herbivores that feed on the crop. Because Cry1Ac has a demonstrated pesticidal activity, the potential for harm to NTOs has been considered as a part of regulatory risk assessments for GE plants that express Cry1Ac, with special consideration to beneficial NTOs that perform valuable functions as well as threatened, endangered and charismatic species
(CFIA, 1996, 1997, 2004, 2005; CTNBio, 2005, 2009; Japan BCH, 1997, 1999, 2007; OGTR, 2002a, 2003b, 2003c, 2005, 2006b; USDA APHIS, 1994, 1996, 1997a, 1997b, 1997c, 2000, 2003; USEPA, 2001). Typically, potential exposures are considered and used to determine what organisms might be impacted by the pesticide, and then these organisms or representative surrogate species can be tested for adverse effects. The impact of pesticides on NTOs is normally determined using a sequential series of tests termed Tier I, Tier II, Tier III and Tier IV (USEPA, 2007). The exact nature of each tier of testing is dependent on the specific case, but in general the level of realism and complexity of tests rise through the tiers (EFSA, 2006; Romeis et al., 2008; Rose, 2007; USEPA, 2007; USEPA, 2010). Early tier studies involve highly controlled laboratory environments where NTO or surrogate species are exposed to high concentrations of the pesticide being studied to determine if there are any effects (Romeis et al., 2008; Rose, 2007; USEPA, 2010; USEPA, 2007). If no effects are observed, additional testing at higher tiers is generally not required (Romeis et al., 2008; Rose, 2007; USEPA, 2010; USEPA, 2007). If adverse effects are observed in early tier tests or unacceptable uncertainty exists, additional testing will progress as necessary through later tiers in order to reduce uncertainty to an acceptable level for decision making (EFSA, 2006; Romeis et al., 2008; USEPA, 2010; USEPA, 2007).

\section{Routes of environmental exposure}

Regulatory decisions have generally considered three primary routes of exposure in addition to direct contact with the GE plant expressing the Cry 1 Ac protein: exposure to pollen containing Cry1Ac, exposure to Cry1Ac deposited in the soil by decomposing plant material, and tritrophic exposure via feeding on herbivores on the GE plant (Japan BCH, 1999; OGTR, 2003; USEPA, 2001). 
A review of the environmental safety of the Cry 1 Ac protein

Table 3. Summary of ecotoxicological tests of Cry1Ac on non-lepidopteran non-target organisms.

\begin{tabular}{|l|l|l|l|}
\hline Species & Method of Exposure & Duration & Results of Observation \\
\hline Apis mellifera (honeybee) larvae & $\begin{array}{l}\text { Single injection of purified protein solution } \\
\text { into cells with developing larvae }\end{array}$ & $\begin{array}{l}\text { 1-3 days after hatching until } \\
\text { adult emergence }\end{array}$ & NOEL 20 ppm \\
\hline Apis mellifera (honeybee) adult & $\begin{array}{l}\text { Feeding purified protein in a honey water } \\
\text { solution }\end{array}$ & NA & NOEL 20 ppm ${ }^{1}$ \\
\hline Nasonia vitripennis & Purified protein in a honey water diet & 23 days & NOEL 20 ppm ${ }^{1}$ \\
\hline Hippodamia convergens (ladybird beetle) & Purified protein in honey water diet & 30 days & NOEL $20 \mathrm{ppm}^{1}$ \\
\hline $\begin{array}{l}\text { Chrysoperla carnea } \text { (green Lacewing) } \\
\text { larvae }\end{array}$ & $\begin{array}{l}\text { Purified protein mixed in a paste of Sitotroga } \\
\text { eggs }\end{array}$ & 11 days & NOEL $20 \mathrm{ppm}^{1}$ \\
\hline Folsomia candida (springtail) & Purified protein in artificial diet & 21 days & NOEL $>200 \mathrm{ppm}^{1}$ \\
\hline Xenylla grisea (springtail) & Purified protein in artificial diet & 21 days & NOEL $>200 \mathrm{ppm}^{1}$ \\
\hline Mus musculum (mouse) & $\begin{array}{l}\text { Single dose oral gavage }>3280 \mathrm{mg} \text { Cry1 Ac/kg } \\
\text { body weight }\end{array}$ & 14 days & No observed effects ${ }^{1}$ \\
\hline
\end{tabular}

${ }^{1}$ Data reported in US EPA (2001) and ANZFA (2002).

Exposure through pollen is limited by the generally low expression levels of Cry1Ac in pollen of varieties that have received regulatory approvals (See Annex I for expression level data in pollen of approved varieties) as well as the rapidly decreasing density of pollen deposition with increasing distance from the source plant (CFIA, 1997; FSANZ, 2004; OGTR, 2002a, 2003b, 2003c, 2005, 2006b, 2008; USDA APHIS, 1994, 1996, 1997a, 1997b, 1997c, 2000, 2003; USEPA, 2001). Although some biologically significant exposure may occur within a short distance of crop fields, regulatory agencies have generally only requested data for the impacts of Cry1Ac on representative pollinator species (i.e., honeybee) (EU SCP, 1998; Japan BCH, 1999; OGTR, 2002b, 2003a, 2003c, 2006a, 2006c; USEPA, 2001). Similarly, the specificity of Cry1Ac toxicity to Lepidoptera and evidence suggesting low exposure through soil has led regulators to require testing for only representative soil dwelling arthropod species (EU SCP, 1998; OGTR, 2002a, 2003b, 2003c, 2005, 2006b; USEPA, 2001). Several reports have indicated that Cry proteins from GE plants can bind to clay substrates in soil and that these bound proteins are protected from microbial digestion but retain their insecticidal activity (Crecchio and Stotsky, 1997; Koskella and Stotzky, 1997; OECD, 2007). These studies used very high concentrations of Cry proteins relative to the amount of binding substrate, representing much higher exposure than is likely to occur in an agricultural environment. Subsequent studies under conditions more relevant to agricultural fields have supported earlier conclusions about the degradation of Cry1Ac with a half life of approximately 9-40 days (Accinelli et al., 2008; Marchetti et al., 2007). In at least one field experiment, Cry1Ac was not detected by ELISA or bioassay in agricultural fields where Cry1 Ac expressing cotton (MON-00531-6) had been grown and tilled into soils for three to six consecutive years (Head et al., 2002). Regulatory approvals of Cry1Ac events have considered information on Cry protein rates of degradation in a range of soil types, but have not required additional soil organism toxicity testing for Cry1Ac (CFIA, 1997; CTNBio, 2005; Japan BCH, 1997, 1999, 2007; OGTR, 2002a, 2003b, 2003c, 2005, 2006b; USDA APHIS, 1994, 1996, 1997a, 1997b, 1997c, 2000, 2003; USEPA, 2001). Potential bitrophic and tritrophic exposures are addressed using ecotoxicological testing.

\section{Ecotoxicological testing of Cry1Ac on non-Lepidopteran NTOs}

NTO testing of purified Cry1Ac has been conducted on a variety of non-lepidopteran species for regulatory submissions related to Cry1Ac producing GE plants (ANZFA, 2002; OECD, 2007; USEPA, 2001). Test organisms included adult and larval Apis mellifera (honeybee), predatory Coleoptera Hippodamia convergens (ladybird beetle) and Neuoptera Chrysoperla carnea (green lacewing), parasitic Hymenoptera Nasonia vitripennis, as well as soil dwelling Collembola (springtail) species Folsomia candida and Xanylla grisea. None of these organisms showed a significant response to Cry $1 \mathrm{Ac}$ at the test concentrations resulting in observations of a No Observed Effects Level (NOEL). Additionally, acute mammalian toxicological testing has been conducted on mouse (Mus musculus) (ANZFA, 2002; USEPA, 2001). The results of all of these studies are summarized in Table 3. 


\section{Ecotoxicological testing of Cry1Ac on the non-target Lepidopteran Danaus plexippus L. (Monarch butterfly)}

Cry 1 proteins are known to have a toxic effect on certain insects of the order Lepidoptera (Crickmore et al., 1998, 2005; Hofte and Whiteley, 1989; OECD, 2007). Because lepidopterans feeding on the plants engineered to express Cry1 proteins are generally considered pests, studies of non-target organisms have considered impacts to Lepidoptera that might be exposed incidentally to Cry proteins. Most of the investigations have centered on the Monarch butterfly (Danaus plexippus), a well known and valued charismatic species in North America. Early monarch butterfly studies (Jesse and Obrycki, 2000; Losey et al., 1999) did not assess Cry1 Ac plant material, however subsequent research has examined the toxicity of Cry1 Ac on monarch larvae in both Tier I studies with purified proteins in an artificial diet and Tier II studies simulating exposure through pollen from maize event DKB-894169 (Hellmich et al., 2001). These studies suggest that monarch larvae are sensitive to Cry $1 \mathrm{Ac}$ and exposure under laboratory conditions can cause delayed development and mortality to monarch larvae. However, exposure to pollen from Cry1Ac expressing maize (event DKB-89416-9) at concentrations $>1600$ pollen grains $/ \mathrm{cm}^{2}$ of milkweed leaf does not affect growth or survival (Hellmich et al., 2001). A study of corn pollen deposition on milkweed in and around cornfields determined that less than $1 \%$ of milkweed leaves within cornfields during the two weeks of anthesis are expected to have concentrations of pollen greater than 900 grains $/ \mathrm{cm}^{2}$ (OECD, 2003; Pleasants et al., 2001). This confirms earlier risk assessments which predicted negligible impacts due to the low exposure of non-target Lepidoptera to pollen or other plant tissue containing Cry1Ac (CFIA, 1997; USDA APHIS, 1994, 1996, 1997a, 1997b, 1997c, 2000, 2003; USEPA, 2001). The results of these studies are summarized in Table 4.

\section{Field studies of Cry1Ac on non-target organisms}

A number of reviews and meta-analyses have analyzed the net results of much of the available literature regarding NTO field studies (Romeis et al., 2006). A database ${ }^{5}$

\footnotetext{
${ }^{5}$ The Nontarget Effects of Bt Crops Database is maintained by the National Center for Ecological Analysis and Synthesis (NCEAS) http://delphi.nceas.ucsb.edu/btcrops/. Papers must meet the following criteria to be included in the database: (i) involve a field crop species that has been genetically transformed to express one or more cry genes derived from Bacillus thuringiensis; (ii) measure effects of the transformed crop for
}

Table 4. Summary of ecotoxicological testing of monarch butterfly (D. plexippus $)^{1}$.

\begin{tabular}{|l|l|l|l|}
\hline Species & $\begin{array}{l}\text { Method } \\
\text { of Exposure }\end{array}$ & Duration & Result \\
\hline $\begin{array}{l}\text { Danaus plexippus } \\
\text { 1st instar larvae }\end{array}$ & $\begin{array}{l}\text { Purified Protein } \\
\text { Incorporated in } \\
\text { test diet }\end{array}$ & 7 days & $\begin{array}{l}\mathrm{LC}_{50}=13.8 \mathrm{ng} / \mathrm{mL} \\
\text { artificial diet }^{2} \\
\mathrm{EC}_{50}=0.9 \mathrm{ng} / \mathrm{mL} \\
\text { artificial diet }^{3}\end{array}$ \\
\hline Danaus plexippus & $\begin{array}{l}\text { Pollen Grains } \\
\text { from DBT418 } \\
\text { dusted on milk- } \\
\text { weed leaves as } \\
\text { food substrate } \\
(100->1600 \\
\text { pollen grains/ } \\
\left.\mathrm{cm}^{2}\right)\end{array}$ & N days & No effects observed \\
\hline
\end{tabular}

${ }^{1}$ Data from Hellmich et al. (2001).

${ }^{2} \mathrm{LC}_{50}=$ Concentration at which $50 \%$ of larval mortality is expected (Lethal Concentration).

${ }^{3} \mathrm{EC}_{50}=$ Concentration expected to produce $50 \%$ growth inhibition by calculation.

compiling this information has been created to facilitate continuing study (Duan et al., 2008, 2010; Marvier et al., 2007; Naranjo, 2009; Wolfenbarger et al., 2008). When GE plants that express Cry proteins, including Cry1Ac cotton, were compared to control plants that were not treated with chemical insecticide there was a reduction in arthropod abundance, but when control plants are treated with insecticide arthropod abundance is significantly higher in GE plants expressing Cry proteins (Marvier et al., 2007; Naranjo, 2009 Wolfenbarger et al., 2008). When comparisons were made between GE plants expressing Cry proteins and controls where insecticide sprays are applied to both, no significant differences were seen (Marvier et al., 2007). Meta-analysis of Cry1Ac cotton data suggest that the reduction in non-target arthropod abundance when compared to unsprayed control was primarily driven by a reduction in Lepidoptera, but smaller reductions in the number of Coeleoptera and Hemiptera were seen as well (Marvier et al., 2007). When arthropods were grouped by functional guilds (Predator, Parasitoid, Mixed, Herbivore, Omnivore, Detritivore) significant reductions in Predators are seen in Cry1Ac cotton as compared to unsprayed control (Naranjo, 2009; Wolfenbarger et al., 2008). This was a consequence of reductions in two families (Nabidae and Coccinellidae) rather than a uniform reduction (Naranjo, 2009; Wolfenbarger et al., 2008). This reduction has been

one or more groups of non-target invertebrate; (iii) include a comparison to a non-transgenic control or a range of exposure levels to the transgenic plant or plant products (e.g. pollen); and (iv) be written in English. 
shown to be inconsequential for biological control of non-target pests (Naranjo, 2005a, 2005b).

\section{ESTABLISHMENT AND PERSISTENCE OF CRY1AC-EXPRESSING PLANTS IN THE ENVIRONMENT}

\section{Biology of the plant species}

Familiarity with the biology of the nontransformed or host plant species in the receiving environment is typically the starting point for environmental risk assessments of GE plants (OECD, 2006). Information about the biology of the host plant can be used to identify species-specific characteristics that may be affected by the novel trait so as to permit the transgenic plant to become "weedy," invasive of natural habitats, or to be otherwise harmful to the environment. It can also provide details on significant interactions between the plant and other organisms that may be important when considering potential harms. By considering the biology of the host plant, a risk assessor can identify potential hazards that may be associated with the expression of the novel protein (e.g., Cry1Ac) and then be able to assess the likelihood of these hazards being realized. For example, if the plant species is highly domesticated and requires significant human intervention to grow or reproduce, the assessor can take that into account when assessing the likelihood of the GE plant establishing outside of cultivation.

\section{Phenotypic data}

Information about the phenotype of GE plants expressing Cry $1 \mathrm{Ac}$ is collected from laboratory, greenhouse and field trial studies and is presented in regulatory submissions to: (1) identify any intentional changes to the phenotype that might impact the environmental safety of the plant; and (2) to identify any unintended changes to the biology of the plant that might impact environmental safety. Phenotypic data in regulatory submissions and peer reviewed publications have focused on characteristics of the plant that might contribute to its survival or persistence (i.e., potential weediness), or that negatively affect agricultural performance (e.g., disease susceptibility and yield data) (CFIA, 1997; CTNBio, 2005; Japan BCH, 1997, 1999, 2007; OGTR, 2002a, 2003b, 2003c, 2005, 2006b; USDA APHIS, 1994, 1996, 1997a, 1997b, 1997c, 2000, 2003). Because the Cry1Ac protein is intended to provide resistance to target insect pests, this is taken into account when phenotypic observations are made. Some of the collected data are quantitative (e.g., plant height or $\%$ seed germination) while other data are qualitative and observational (e.g. no differences in disease susceptibility) (USDA APHIS, 1994, 1996, 1997a, 1997b, 1997c, 2000, 2003). Statistically significant differences were seen between GE plants expressing Cry $1 \mathrm{Ac}$ and controls in many cases, but these differences were small and fell within the reported range for the crop species (USDA APHIS, 1994, 1996, 1997a, 1997b, 1997c, 2000, 2003). Collectively, the phenotypic data showed no pattern of changes that would support the hypothesis that the introduction of Cry1Ac protein had any unintended impact on the gross morphology or phenotypic characteristics of plants, besides conferring insect resistance to Lepidoptera pests. The phenotypic data for GE plants expressing Cry1Ac is summarized in Annex II.

\section{Weediness in agricultural environments}

Both maize and cotton have some potential to "volunteer" as weeds in subsequent growing seasons (OECD, 2003; OECD, 2008; OGTR, 2008). The characteristics that influence the ability of a plant to volunteer are largely the same as those for weediness in general such as seed dormancy, shattering, and competitiveness (Baker, 1974). There are no data indicating a linkage between Cry1Ac protein expression and any increased survival or overwintering capacity that would alter the prevalence of volunteer maize or cotton in subsequent growing seasons (CFIA, 1997; CTNBio, 2005; Japan BCH, 1997, 1999, 2007; OGTR, 2002a, 2003b, 2003c, 2005, 2006b; USDA APHIS, 1994, 1996, 1997a, 1997b, 1997c, 2000, 2003). Following-season volunteers expressing Cry1Ac would not be expected to present any management difficulty and can be dealt with in the same manner as conventional volunteers of maize and cotton.

\section{Weediness in non-agricultural environments}

The primary mechanisms by which Cry $1 \mathrm{Ac}$ may be introduced into a non-agricultural environment are movement and establishment of the GE plant outside of cultivated areas, and gene flow from the GE plant to a naturalized population or other sexually compatible relatives (Mallory-Smith and Zapiola, 2008). Risk assessments for GE plants expressing Cry1Ac have considered the potential impacts associated with both types of movement (CFIA, 1997; CTNBio, 2005; Japan BCH, 1997, 1999, 2007; OGTR, 2002a, 2003b, 2003c, 2005, 2006b; USDA APHIS, 1994, 1996, 1997a, 1997b, 1997c, 2000, 2003).

While all plants can be considered weeds in certain contexts, neither maize nor cotton is considered to be an invasive or aggressive weed outside of agricultural 
systems. Maize is severely restricted in ability to establish without human intervention but cotton can persist under favorable conditions and may at times require management (OECD, 2003; OECD, 2008; OGTR, 2008). Agronomic data show that Cry1Ac does not have a significant impact on traits associated with weediness (CFIA, 1997; CTNBio, 2005; Japan BCH, 1997, 1999, 2007; OGTR, 2002a, 2003b, 2003c, 2005, 2006b; USDA APHIS, 1994, 1996, 1997a, 1997b, 1997c, 2000, 2003). Although release from natural control factors (including insect herbivores) has been offered as a partial explanation for the success of invasive species (Blumenthal, 2005; Keane and Crawley, 2002; Mack, 1996; Mason et al., 2004) most regulatory decisions have agreed that it is unlikely that the addition of resistance to Lepidopteran pests would allow cotton expressing Cry1 Ac to become invasive of non-agricultural environments (CFIA, 1997; CTNBio, 2005; Japan BCH, 1997, 1999, 2007USDA APHIS, 1994, 1996, 1997a, 1997b, 1997c, 2000, 2003). Regulatory decisions in Australia prior to 2006 restricted the release of Cry1Ac cotton in Northern Australia because of uncertainty about the impact of insect- resistance on the ability of cotton to persist. Subsequent studies, however, indicated that lepidopteran herbivory was not significant in limiting the spread of cotton in Northern Australia and the restriction was lifted (OGTR, 2002a, 2003b, 2003c, 2005, 2006b, 2006c).

\section{Movement of the transgene to sexually compatible relatives}

The movement of transgenes from a GE plant to its wild relatives is pollen mediated and the production of reproductively viable hybrids depends on the physical and temporal proximity of the GE plants to sexually compatible species. Neither maize nor cotton has wild relatives that are considered invasive of ecosystems or broadly distributed, agriculturally important weeds for which hybridization is a concern (OECD, 2003; OECD, 2008; OGTR, 2008). Maize freely hybridizes with wild teosintes, but gene introgression is thought to be limited (Baltazar et al., 2005; OECD, 2003; Serratos et al., 1995). Wild teosinte populations are limited to Mexico, Guatemala and a single population in Nicaragua and while teosinte is considered a serious weed by some farmers in Mexico, it is treated as a beneficial by others (Serratos et al., 1995). Cotton has several wild relatives with which it might potentially hybridize (OECD, 2008; OGTR, 2008). The USEPA has restricted the release of Cry1Ac expressing cotton in Hawaii due to uncertainty about the effects on populations of $G$. tomentosum (USEPA, 2001). USEPA has also restricted release in Southern Florida because of uncertainty about the impact of gene flow to naturalized $G$. hirsutum with respect to the development of insect resistance (USEPA, 2001). In Australia, uncertainty about the impact of gene flow to naturalized populations of G. hirsutum and G. barbadense led to restriction on the planting of Cry1Ac cotton in Northern Australia until 2006, when studies established that Lepidoptera predation was not significant in controlling these populations (OGTR, 2002a, 2003b, 2003c, 2005, 2006b, 2006c). Brazil has established an exclusion zone for the growth of Cry1Ac cotton as well, to prevent potential gene flow to wild species in northwestern Brazil (CTNBio, 2005).

\section{COMPOSITIONAL ANALYSIS OF CRY1AC PLANTS}

Detailed compositional analysis is a scientifically rigorous component of the characterization of GE plants and is a regulatory requirement for GE food and feed safety approvals (Codex, 2003a, 2003b; EFSA, 2006A; FAO/WHO, 1996; OECD, 1992; WHO, 1995). The choice of analyses conducted depends on the nature of the product and its intended uses. Insect resistant GE crops expressing Cry1 Ac have typically undergone proximate analysis (crude protein, crude fat, fiber, moisture and ash) (ANZFA, 2002; Berberich et al., 1996; CFIA, 1996, 1997, 2002, 2003, 2005; CTNBio, 2005; Hamilton et al., 2004; Japan BCH, 1997, 1999, 2007; OGTR, 2002a, 2003b, 2003c, 2005, 2006b; USDA APHIS, 1994, 1996, 1997a, 1997b, 1997c, 2000, 2003). Detailed analyses of fatty acid and amino acid composition have also been conducted, as well as analyses of important secondary metabolites that have toxic or anti-nutritional properties (e.g gossypol in cotton) (ANZFA, 2002; Berberich et al., 1996; CFIA, 1996, 1997, 2002, 2003, 2005; CTNBio, 2005; Hamilton et al., 2004; Japan BCH, 1997, 1999, 2007; OGTR, 2002a, 2003b, 2003c, 2005, 2006b; USDA APHIS, 1994, 1996, 1997a, 1997b, 1997c, 2000, 2003). The data collected can be useful as indicators of unintended changes to the transformed plant (Codex, 2003a, 2003b; Nickson and McKee, 2002).

Data from publicly available compositional analyses are summarized in Annex III. Although some statistically significant compositional differences were observed the composition of GE plants expressing Cry1Ac was found to fall within the normal range observed in the crop species (ANZFA, 2002; Berberich et al., 1996; Hamilton et al., 2004; USDA APHIS, 1996, 1997c, 2000, 2003). Subsequent regulatory analyses did not consider these differences to be meaningful in the context of 
environmental safety (CFIA, 1997; CTNBio, 2005; Japan BCH, 1997, 1999, 2007; OGTR, 2002b, 2003a, 2003c, 2006a, 2006c; USDA APHIS, 1995, 1997d, 2001, 2004).

Considering data across approved events, there have been no patterns of consistent or reliable changes in proximate composition in plants expressing Cry1Ac. This indicates that the expression of Cry1Ac does not have any biologically significant effect on the gross metabolism of the transformed plants.

\section{CONCLUSION}

The Cry1Ac protein expressed in insect resistant GE plants is derived from the common soil bacterium Bacillus thuringiensis and is specifically toxic to Lepidoptera. Toxicity testing with a range of representative nontarget organisms (NTOs) produced NOEL values at concentrations representing ten-fold or higher the expected environmental concentrations of Cry1Ac. Meta analyses of field studies suggest that cultivation of GE cotton plants expressing Cry1Ac slightly reduced the abundance of non-target arthropods when compared to unsprayed cotton, increased arthropod abundance when compared to cotton sprayed with insecticides and had no discernable effect when both the GE plants and controls were treated with insecticide consistent with conventional insect management practices. Cry1 Ac in plants can be toxic to non-target Lepidoptera, but regulatory risk assessments for approved products have concluded that the low likelihood of exposure results in negligible additional risk compared to other agricultural practices. The weight of evidence from analyses of phenotypic and compositional data demonstrates that Cry1 Ac expression in approved cotton and maize events did not alter the gross physiology of the plant, and that these plants are not more likely to become weedy or invasive than their conventional counterparts.

\section{REFERENCES}

\section{Journal Articles and Books}

Accinelli C. Koskinen W. C., Becker J. M. and Sadowsky M. J. (2008). Mineralization of the Bacillus thuringiensis Cry1Ac endotoxins in soil. Journal of Agricultural and Food Chemistry. 56:1025-1028.

Aronson A. I. and Shai Y. (2001). Why Bacillus thuringiensis insecticidal toxins are so effective: unique features of their mode of action. FEMS Microbiology Letters 195: 1-8.

Baker H.G. (1974). The evolution of weeds. Annual Review of Ecology and Systematics 5: 1-24.

Baltazar B.M., Sanchez-Gonzales J. J., Cruz-Larios, L., and Schoper, J.B. (2005). Pollination between maize and teosinte: an important determinant of gene flow in Mexico. Theoretical Applied Genetics 110:519-526.

Berberich S. A., Ream J. E., Jackson T. L., Wood R., Stipanovic R., Harvey P., Patzer S. and Fuchs R. L. (1996). The composition of insect-protected cottonseed is equivalent to that of conventional cottonseed. Journal of Agricultural and Food Chemistry 44(1):365-371.

Blumenthal D. (2005). Interrelated causes of plant invasion. Science 310: 243-244

Bravo A. Gill S. S. and Soberon M. (2007). Mode of action of Bacillus thuringiensis Cry and Cyt toxins and their potential for insect control. Toxicon. 49(4): 423-435. http://www. pubmedcentral.nih.gov/articlerender.fcgi?artid=1857359

CERA. (2010). GM Crop Database. Center for Environmental Risk Assessment (CERA), ILSI Research Foundation, Washington D.C. http://cera-gmc.org/index.php?action=gm crop_database

Crecchio C. and Stotsky G. (1998). Insecticidal activity and biodegradation of the toxin from Bacillus thuringiensis subsp. Kurstaki bound to humic acids from soil. Soil Biology and Biochemistry 30(4):463-470.

Crickmore N., Zeigler D. R., Feitelson J., Schnepf E., Van Rie J., Lereclus D., Baum J. and Dean D. H. (1998). Revision of the nomenclature for the Bacillues thuringiensis pesticidal crystal proteins. Microbiology and Molecular Biology Reviews 62(3): 807-813.

Crickmore N., Zeigler D.R., Schnepf E., Van Rie J., Lereclus D., Baum J., Bravo A., and Dean D.H. (2005). Bacillus thuringiensis Toxin Nomenclature (Homepage). [cited January 2010]. http://www.lifesci.sussex.ac.uk/Home/Neil_ Crickmore/Bt/.

Duan JJ, Marvier M, Huesing J, Dively G, Huang ZY (2008) A meta-analysis of effects of Bt crops on honey bees (Hymenoptera: Apidae). PLoS ONE 3(1):e1415

Duan JJ, Lundgren JG, Naranjo S, Marvier M (2010) Extrapolating non-target risk of Bt crops from laboratory to field. Biol Lett 6:74-77

Ellstrand N.C. (2003). Current knowledge of gene flow in plants: implications for transgene flow. Philosophical Transactions of the Royal Society, Series B 358:1163-1170.

Hamilton K. A., Pyla P.D., Breeze M., Olson T., Li M., Robinson E., Gallagher S. P., Sorbet R. and Chen Y. (2004). Bollgard II cotton: compositional analysis and feeding studies of cottonseed from insect-protected cotton (Gossypium hirsutum L.) producing the Cry1 Ac and Cry2Ab2 proteins. Journal of Agricultural and Food Chemistry 52: 6969-6976.

Head G., Surber J. B., Watson J. A., Martin J. W. and Duan J. J. (2002). No detection of Cry1Ac protein in soil after multiple years of transgenic Bt cotton (Bollgard) use. Environmental Entomology 43(1): 30-36.

Hellmich R. L. Siegfried B. D., Sears M. K., Stanley-Horn D. E., Daniels M. J., Mattila H. R., Spencer T., Bidne K. G. and Lewis L. C. (2001). Monarch larvae sensitivity to Bacillus thuringiensis-purified proteins and pollen. Proceedings of the National Academies of Science (U.S.A.) 98(21):1192511930. 
Hofte H. and Whiteley H. R. (1989). Insecticidal crystal proteins of Bacillus thuringiensis. Microbiological Reviews 53(2): 242-255.

Jenkins J. L., Lee M. K., Sangadala S., Adang M. J. and Dean D. H. (1999). Binding of Bacillus thuringiensis Cry1Ac toxin to Manduca sexta aminopeptidase-N receptor is not directly related to toxicity. FEBS Letters 462: 373-376.

Jesse L. C. H. and Obrycki J. J. (2000). Field deposition of Bt transgenic corn pollen: lethal effects on the monarch butterfly. Oecologia 125:241-248.

Keane R. M. and Crawley M. J. (2002). Exotic plant invasions and the enemy release hypothesis. Trends in Ecology and Evolution 17(4):164-170.

Koskella J. and Stotzky G. (1997). Microbial utilization of free and clay-bound insecticidal toxins from Bacillus thuringiensis and their retention of insecticidal activity after incubation with microbes. Applied and Environmental Microbiology 63(9): 3561-3568.

Kumar P. A., Sharma R. P. and Malik V.S. (1996). The insecticidal proteins of Bacillus thuringiensis. Advances in Applied Microbiology 42: 1-43.

Losey J. E., Rayor L. S., Carter M. E. (1999). Transgenic pollen harms monarch larvae. Nature 399: 214.

Mack R.N. (1996) Predicting the identity and fate of plant invaders: emergent and emerging approaches. Biological Conservation 78:107-121.

Mallory-Smith C., and Zapiola M. (2008). Gene flow from glyphosate-resistant crops. Pest Management Science 64: 428-440.

Marchetti E., Accinelli C., Talame V. and Epifani R. (2007). Persistence of Cry toxins and cry genes from genetically modified plants in two agricultural soils. Agronomy for Sustainable Development 27(3): 231-236.

Marvier M., McCreedy C., Regetz J., Kareiva P. (2007). A meta-analysis of effects of $B t$ cotton and maize on nontarget invertebrates. Science 316:1475-1477.

Mason P., Braun L., Warwick S.I., Zhu B., Stewart Jr. C.N. (2003) Transgenic Bt-producing Brassica napus: Plutella xylostella selection pressure and fitness of weedy relatives. Environmental Biosafety Research 2:263-276.

Naranjo S.E. (2005a) Long-term assessment of the effects of transgenic Bt cotton on the abundance of non-target arthropod natural enemies. Environmental Entomology 34: 1193-1210.

Naranjo, S.E. (2005b) Long-term assessment of the effects of transgenic Bt cotton on the function of the natural enemy community. Environmental Entomology 34: 1211-1223.

Naranjo S. E. (2009). Impacts of $B t$ crops on non-target invertebrates and insecticide use patterns. CAB Reviews: Perspectives in Agriculture, Veterinary Science, Nutrition and Natural Resources 4(11): http://fbae.org/2009/FBAE/website/ images/pdf/imporatant-publication/impacts-of-bt-crops-onnon-target-invertebrates-and-insecticide-use-patterns.pdf

Nickson T. E. and McKee M. J. (2002). Ecological assessment of crops derived through biotechnology. In Thomas J. A. and Fuchs R. L. (eds.) Biotechnology and safety assessment (third edition)(pp233-252). Academic Press, San Diego, CA
NRC (1989). Field testing genetically modified organisms: framework for decisions. National Academy of Sciences, National Research Council (NRC) committee on Scientific Evaluation of the Introduction of Genetically Modified Microorganisms and Plants into the Environment. National Academy Press, Washington, D.C.

NRC (2000). Genetically modified pest-protected plants: science and regulation. National Academy of Sciences, National Research Council (NRC). National Academy Press, Washington D.C.

NRC (2002). Environmental effects of transgenic plants: the scope and adequacy of regulation. National Academy of Sciences, National Research Council (NRC). National Academy Press, Washington D.C.

Pleasants J. M., Hellmich R. L., Dively G. P., Sears M. K., Stanley-Horn D. E., Mattila H. R., Foster J. E., Clark P. and Jones G. D. (2001). Corn pollen deposition on milkweeds in and near cornfields. Proceedings of the National Academies of Sciences (USA) 98(21): 11919-11924. http://www.pnas. org/content/98/21/11919.full

Rose R.I. (ed.) (2007) White paper on tier-based testing for the effects of proteinaceous insecticidal plant-incorporated protectants on non-target invertebrates for regulatory risk assessment. USDA-APHIS and US Environmental Protection Agency, Washington, DC, USA. http://www.epa.gov/ pesticides/biopesticides/pips/non-target-arthropods.pdf

Romeis J., Meissle M . and Bigler F. (2006). Transgenic crops expressing Bacillus thuringiensis toxins and biological control. Nature Biotechnology 24(1): 63-71.

Romeis J., Barsch D., Bigler F., Candolfi M. P., Gielkens M. M. C., Hartley S.E., Hellmich R. I., Huesing J. E., Jepson P. C., Layton R., Quemada H., Raybould A., Rose R. I., Schiemann J., Sears M. K., Shelton A. M., Sweet J., Vaituzis Z., and Wolt J. D. (2008). Assessment of risk of insect-resistant transgenic crops to nontarget arthropods

Serratos J.A., Wilcox M.C., CastilloF.(Eds.) (1995). Proceedings of a Forum: Gene flow among maize landraces, improved maize varieties, and teosinte: implications for transgenic maize. The Mexican National Institute of Forestry Agriculture and Livestock Research (INIFAP), The International Maize and Wheat Improvement Center (CIMMYT), and The Mexican National Agricultural Biosafety Committee (CNBA).

Schnepf E., Crickmore N., van Rie J., Lereclus D., Baum J., Fetelson J., Ziegler D. R. and Dean D. H. (1998). Bacillus thuringiensis and its pesticidal crystal proteins. Microbiology and Molecular Biology Reviews 62(3): 775-806.

Tabashink B.E. (1992). Evaluation of synergism among Bacillus thuringiensis toxins. Applied and Environmental Microbiology 58(10): 3343-3346.

Wolfenbarger L. L., Naranjo S. E., Lundgren J. G., Bitzer R. J. and Watrud L. S. (2008). Bt crops effects on functional guilds of non-target arthropods: a meta-analysis. PloS One 3(5): e2118 http://www.ncbi.nlm.nih.gov/pmc/articles/ PMC2346550/pdf/pone.0002118.pdf

Zhang X., Candas M., Griko N. B., Taussig R., Bulla L. A. Jr. (2006). A mechanism of cell death involving an adenylyl 
cyclase/PKA signaling pathway is induced by the Cry $1 \mathrm{Ab}$ toxin of Bacillus thuringiensis. Proceedings of the National Academies of Science (U.S.A.) 103(26):9897-9902.

\section{Regulatory Publications}

ANZFA (2002) Draft assessment report application A380: Food from insect-protected and glufosinate ammonium-tolerant DBT418 corn. Australia New Zealand Food Authority (ANZFA), Canberra, Australia and Wellington, New Zealand. APVMA (2010). Public Chemical Information System (PUBCRIS) [Search for Bacillus thuringiensis]. Australian Pesticides and Veterinary Management Authority (AVPMA), Symonston, Australia. http://services.apvma.gov.au/ PubcrisWebClient/welcome.do

CBD (2000a). Cartagena Protocol on Biosafety. Secretariat of the Convention on Biological Diversity (CBD), Montreal. http://www.cbd.int/biosafety/protocol.shtml.

CBD (2000b). Cartagena Protocol on Biosafety Annex III: Risk Assessment. Secretariat of the Convention on Biological Diversity (CBD), Montreal. http://www.cbd.int/biosafety/ articles.shtml?a=cpb-43

CFIA (1996). Decision document 96-14: Determination of environmental safety of Bollgard insect resistant cotton (Gossypium hirsutum L.). Canadian Food Inspection Agency (CFIA) Ottawa, Canada. http://www.inspection.gc.ca/ english/plaveg/bio/dd/dd9614e.shtml

CFIA (1997). Decision Document 98-23: Determination of Dekalb Genetics Corporation's European Corn Borer Resistant Corn (Zea mays L.) Line DBT418. Canadian Food Inspection Agency (CFIA) Ottawa, Canada. http://www. inspection.gc.ca/english/plaveg/bio/dd/dd9823e.shtml

CFIA (2002). Canada - U.S. bilateral agreement on agricultural biotechnology Appendix II: environmental characterization data for transgenic plants intended for unconfined release. http://www.inspection.gc.ca/english/plaveg/bio/usda/ appenannex2e.shtml

CFIA (2003). Decision document DD2003-45: Determination of the safety of Monsanto's insect resistant Bollgard II cotton (Gossypium hirsutum L.). Canadian Food Inspection Agency (CFIA) Ottawa, Canada. http://www.inspection.gc.ca/ english/plaveg/bio/dd/dd0345e.shtml

CFIA (2005). Decision document DD2005-51: Determination of the safety of Dow AgroSciences Inc. insect resistant cotton (Gossypium hirsutum) event 3006-210-23. Canadian Food Inspection Agency (CFIA) Ottawa, Canada. http://www. inspection.gc.ca/english/plaveg/bio/dd/dd0551e.shtml

CFIA (2009). Introduction to CFIA's policy on managing cases of non-compliance. Canadian Food Inspection Agency (CFIA) Ottawa, Canada. http://www.inspection.gc.ca/ english/plaveg/bio/nonapp/nonappe.shtml.

Codex (2003a). Principles for the risk analysis of foods derived through modern biotechnology. Codex Alimentarius Commission (Codex), Rome http://www.codexalimentarius. net/download/standards/10007/CXG_044e.pdf.
Codex (2003b). Guideline for the conduct of food safety assessment of foods derived from recombinant DNA plants. Codex Alimentarius Commission (Codex), Rome http:// www.codexalimentarius.net/download/standards/10021/ CXG_045e.pdf.

CTNBio (2005). Commercial release of genetically modified cotton, Bollgard Cotton (531). Brazilian National Biosafety Technical Commission (CTNBio), Sao Paulo http://www. ctnbio.gov.br/index.php/content/view/3663.html

CTNBio (2009). Commercial release of genetically modified cotton, Bollgard Cotton (MON 15985): Technical Opinion no. 1832/2009. Brazilian National Biosafety Technical Commission (CTNBio), Sao Paulo.

EC (2001). Directive 2001/18/EC of the European Parliament and of the Council. European Commission, Brussels Belgium. http://ec.europa.eu/environment/biotechnology/ pdf/dir2001_18.pdf.

EFSA (2006a). Guidance document of the scientific panel on genetically modified organisms for the risk assessment of genetically modified plants and derived food and feed. European Food Safety Authority (EFSA), Brussels, Belgium. http://www.efsa.europa.eu/en/scdocs/doc/gmo_guidance_ derived_feed_food.pdf.

EU DG ARD (2007). Economic impact of unapproved GMOs on EU feed imports and livestock production. European Directorate General of Agriculture and Rural Development (EU DG ARD), Brussels, Belgium.

EU DG SANCO (2010). EU Pesticides Database [Search for Bacillus thuringiensis]. European Union Directorate General, Health and Consumers (EU DG SANCO) Brussels, Belgium http://ec.europa.eu/sanco_pesticides/public/index. cfm?event=activesubstance.selection

EU SCP (1998). Opinion of the scientific committee on plants on the genetically modified cotton in, insect-tolerant notified by the Monsanto company (notification C/ES/96/02). European Commission Health and Consumer Protection Scientific Committee on Plants, Brussels.

FAO/WHO (1996). Biotechnology and food safety. Report of a Joint FAO/WHO Consultation. Food and Agriculture Organization (FAO)/ World Health Organization (WHO), Food and Nutrition Paper 61, Rome, Italy. http://www.fao. org/ag/agn/food/pdf/biotechnology.pdf.

FAO/WHO (2006). Food safety risk analysis: a guide for national food safety authorities. Food and Agriculture Organization (FAO) and World Health Organization (WHO), Rome. http://www.who.int/entity/foodsafety/publications/ micro/riskanalysis06.pdf.

FSANZ (2004). Final assessment report application A518: Food derived from insect-protected, herbicide-tolerant cotton line MXB-13. Food Safety Australia New Zealand (FSANZ) Canberra, Australia and Wellington, New Zealand. http://www.foodstandards.gov.au/standardsdevelopment/ applications/applicationa518foodd2314.cfm

Japan BCH (1997). Outline of the biological diversity and risk assessment report (Mon-00531-6). Japan Biosafety Clearing House (BCH). Tokyo, Japan. 
Japan BCH (1999). Biological diversity risk assessment report: DBT418. Japan Biosafety Clearing House (BCH). Tokyo, Japan.

Japan BCH (2007). Outline of the biological diversity risk assessment report: Type 1 use approval for cotton LLCotton25 x MON15985 (ACS-GHØØ1-3 x MON-159857). Japan Biosafety Clearing House (BCH). Tokyo, Japan.

OECD (1992). Recombinant DNA safety considerations. Organization for Economic Cooperation and Development (OECD), Paris, France.

OECD (1993). Safety considerations for biotechnology: scaleup of crop plants. . Organization for Economic Cooperation and Development (OECD), Paris, France.

OECD (2003a). Consensus document on the biology of Zea mays subsp. Mays. Organization for Economic Cooperation and Development (OECD), Paris, France.

OECD (2003b). Description of selected key generic terms used in chemical hazard/risk assessment. Organization for Economic Cooperation and Development (OECD), Paris. http://www.olis.oecd.org/olis/2003doc.nsf/LinkTo/ NT00004772/\$FILE/JT00152557.PDF

OECD (2006). Points to consider for consensus documents on the biology of cultivated plants. Organization for Economic Cooperation and Development (OECD), Paris, France.

OECD (2007) Consensus Document on Safety Information on Transgenic Plants Expressing Bacillus thuringiensis Derived Insect Control Protein. Series on Harmonisation of Regulatory Oversight in Biotechnology, No. 42. Organisation for Economic Co-operation and Development, Paris.

OECD (2008). Consensus document on the biology of cotton (Gossypium spp.). Organization for Economic Cooperation and Development (OECD), Paris, France.

OECD (2009). OECD schemes for the varietal certification or the control of seed. Organization for Economic Cooperation and Development (OECD), Paris, France.

OGTR (2002a).DIR 012/2002 Risk Assessment and Risk Management Plan: Commercial Release of Bollgard II cotton. Office of the Gene Technology Regulator (OGTR), Canberra, Australia. http://www.ogtr.gov.au/internet/ogtr/publishing. nsf/Content/dir012-2002

OGTR (2003a) Notification of decision to issue a license on cotton application DIR023/2002. Office of the Gene Technology Regulator (OGTR), Canberra, Australia. http:// www.ogtr.gov.au/internet/ogtr/publishing.nsf/Content/ dir023-4/\$FILE/dir023notific.rtf

OGTR (2003b) Risk assessment and risk management plan for DIR023/2002. Office of the Gene Technology Regulator (OGTR), Canberra, Australia. http://www.ogtr. gov.au/internet/ogtr/publishing.nsf/Content/dir023-3/\$FILE/ dir023finalrarmp.pdf

OGTR (2003c). DIR 022/2002 - Application and license for dealings involving an intentional release into the environment: Commercial release of insecticidal (INGARD event 531) cotton. Office of the Gene Technology Regulator (OGTR), Canberra, Australia. http://www.ogtr.gov.au/internet/ogtr/ publishing.nsf/Content/dir022-4/
OGTR (2005). Full risk assessment and risk management plan for commercial release of genetically modified cotton lines (MON-15985-7, MON-88913-8). Office of the Gene Technology Regulator (OGTR), Canberra, Australia. http:// www.ogtr.gov.au/internet/ogtr/publishing.nsf/Content/ dir059-3/\$FILE/dir059finalrarmp1.pdf

OGTR (2006a). Dir 059/2005 Notification of decision to issue a license. Office of the Gene Technology Regulator (OGTR), Canberra, Australia. http://www.ogtr.gov.au/internet/ogtr/ publishing.nsf/Content/dir059-3/\$FILE/dir059notific.pdf

OGTR (2006b). Full risk assessment and risk management plan (RARMP) for commercial release of genetically modified (GM) herbicide tolerant and/or insect resistant cotton lines north of latitude 22o south. Office of the Gene Technology Regulator (OGTR), Canberra, Australia. http://www.ogtr. gov.au/internet/ogtr/publishing.nsf/Content/dir066-3/\$FILE/ dir066rarmp2.pdf

OGTR (2006c). Decision on issuing a license for application DIR 066/2006: Commercial release of five herbicide tolerant and/or insect resistant GM cotton lines in Northern Australia. Office of the Gene Technology Regulator (OGTR), Canberra, Australia. http://www.ogtr.gov.au/internet/ogtr/publishing. nsf/Content/dir066-3/\$FILE/dir066notifc.pdf

OGTR (2008). The biology of Gossypium hirsutum L. and Gossypium barbadense L. Office of the gene technology regulatory (OGTR) Department of Health and Ageing, Canberra, Australia.

OGTR (2009a). Risk analysis framework. Office of the gene technology regulatory (OGTR) Department of Health and Ageing, Canberra, Australia.

OGTR (2009b). Operations of the gene technology regulator annual report (08-09). Office of the gene technology regulatory (OGTR) Department of Health and Ageing, Canberra, Australia.

PMRA (2008). Re-evaluation decision document: Bacillus thuringiensis. Health Canada, Pest Management Regulatory Agency (PMRA), Ottawa. [accessed Feb18, 2010] http:// www.hc-sc.gc.ca/cps-spc/pubs/pest/_decisions/rvd2008-18/ index-eng.php

USDA APHIS (1994). Petition for determination of nonregulated status: Bollgard cotton line 531 (Gossypium hirsutum L.) with the gene from Bacillus thuringiensis subsp. kurstaki. http://www.aphis.usda.gov/brs/aphisdocs/94_30801p.pdf.

USDA APHIS (1995). USDA/APHIS determination on a petition 94-308-01 of Monsanto Agricultural Company seeking nonregulated status of lepidopteran-resistant cotton lines 531, 757, 1076. United States Department of Agriculture, Animal and Plant Health Inspection Service, Washington D.C. http://www.aphis.usda.gov/brs/aphisdocs2/94_30801p_ com.pdf

USDA APHIS (1996). Petition for determination of nonregulated status: Insect protected corn (Zea mays L.) with the $\operatorname{cryIA}(c)$ gene from Bacillus thuringiensis subsp. Kurstaki. United States Department of Agriculture, Animal and Plant Health Inspection Service, Washington D.C. http:// www.aphis.usda.gov/brs/aphisdocs/96_29101p.pdf. 
USDA APHIS (1997a). Petition for determination of nonregulated status: Insect resistant tomato line 5345 (Lycopersicon esculentum)producing the Cry1Ac insect control protein of Bacillus thuringiensis subsp. kurstaki. United States Department of Agriculture, Animal and Plant Health Inspection Service, Washington D.C. http://www. aphis.usda.gov/brs/aphisdocs/97_28701p.pdf.

USDA APHIS (1997b). Petition for the determination of nonregulated status: BXN with Bt cotton. United States Department of Agriculture, Animal and Plant Health Inspection Service, Washington D.C. http://www.aphis.usda. gov/brs/aphisdocs/97_01301p.pdf

USDA APHIS (1997c) USDA/APHIS petition 97-013-01 p for determination of nonregulated status for events 31807 and 31808. United States Department of Agriculture, Animal and Plant Health Inspection Service, Washington D.C. http:// www.aphis.usda.gov/brs/aphisdocs2/97_01301p_com.pdf

USDA APHIS (1997d). USDA/APHIS petition 96-291-01p for determination of nonregulated status for insect-protected Corn Line DBT418 Environmental Assessment and Finding of No Significant Impact. United States Department of Agriculture, Animal and Plant Health Inspection Service, Washington D.C. http://www.aphis.usda.gov/brs/aphisdocs2/96_29101p_ com.pdf

USDA APHIS (2000). Request for determination of nonregulated status for the regulated article: Bollgard II cotton event 15985 (Gossypium hirsutum L.) producing the Cry2Ab insect control protein derived from Bacillus thuringiensis subsp. kurstaki. United States Department of Agriculture, Animal and Plant Health Inspection Service, Washington D.C. http://www.aphis.usda.gov/brs/aphisdocs/00_34201p. pdf

USDA APHIS (2001). Approval of Monsanto Company Petition (00-342-01p) seeking a determination of nonregulated status for Bollgard II cotton event 15985 producing the Cry2Ab insect control protein derived from Bacillus thuringiensis subsp. kurstaki. United States Department of Agriculture, Animal and Plant Health Inspection Service, Washington D.C. http://www.aphis.usda.gov/brs/aphisdocs2/00_34201p_ com.pdf

USDA APHIS (2003). Petition for determination of nonregulated status: B.t. Cry1Ac insect-resistant cotton event 3006-210-23. United States Department of Agriculture, Animal and Plant Health Inspection Service, Washington D.C. http://www.aphis.usda.gov/brs/aphisdocs/03_03602p. pdf.

USDA APHIS (2004). Approval of Mycogen/Dow petitions 03-036-01p and 03-036-02p seeking determinations of nonregulated status for insect-resistant cotton events 28124-236 and 3006-210-23 genetically engineered to express synthetic B.t. Cry1F and Cry1Ac, respectively: Environmental Assessment and Finding of No Significant Impact. United
States Department of Agriculture, Animal and Plant Health Inspection Service, Washington D.C. http://www.aphis.usda. gov/brs/aphisdocs2/03_03601p_com.pdf

USDA APHIS (2007b). APHIS policy on responding to the low-level presence of regulated genetically engineered plant materials. United States Department of Agriculture, Animal and Plant Health Inspection Service, Washington D.C.

USEPA (1992). Framework for ecological risk assessment. Risk Assessment Forum, U.S. Environmental Protection Agency (USEPA), Washington D. C. http://oaspub.epa.gov/ eims/eimscomm.getfile?p_download_id=36361http://cfpub. epa.gov/ncea/cfm/recordisplay.cfm?deid $=30759$.

USEPA (1998). Guidelines for ecological risk assessment. Risk Assessment Forum, U.S. Environmental Protection Agency (USEPA), Washington D. C. http://oaspub.epa.gov/eims/ eimscomm.getfile?p_download_id=36512 .

USEPA (2001). Bt Plant-Incorporated Protectants October 15, 2001 Biopesticides Registration Action Document. U.S. Environmental Protection Agency (USEPA), Washington D. C. http://www.epa.gov/pesticides/biopesticides/pips/bt_brad. htm

USEPA (2007). White paper on tier-based testing for the effects of proteinaceous insecticidal plant-incorporated protectants on non-target arthropods for regulatory risk assessments. U.S. Environmental Protection Agency (USEPA), Washington D. C. http://www.epa.gov/pesticides/biopesticides/pips/nontarget-arthropods.pdf

USEPA (2010). The Office of Prevention, Pesticides and Toxic Substances (OPPTS), Harmonized Test Guidelines. U.S. Environmental Protection Agency (USEPA), Washington D. C. http://epa.gov/oppts/pubs/frs/home/guidelin.htm

USFDA (1997). Biotechnology Consultation Note to the File BNF No. 000047. U.S. Food and Drug Administration, Silver Spring MD. http://www.fda.gov/Food/Biotechnology/ Submissions/ucm161166.htm

WHO (1995). Application of the Principles of Substantial Equivalence to the Safety Evaluation of Foods or Food Components from Plants Derived by Modern Biotechnology. A Report of a WHO Workshop. World Health Organisation (WHO), Geneva.

\section{ANNEX I: SUMMARY OF CRY1AC PROTEIN EXPRESSION DATA}

The tables that follow present summary data from peer-reviewed publications and regulatory submissions. The data is presented in the format in which it is available in the cited document in order to facilitate crossreferencing. Additional information on collection and sampling methodologies can be found in the referenced sources. 
Table I.1. Expression of Cry1Ac in Zea mays event DBT418 (USDA APHIS, 1996) ${ }^{1}$.

\begin{tabular}{|c|c|c|c|c|c|c|c|c|c|c|c|}
\hline \multirow[t]{2}{*}{ Tissue } & \multirow[t]{2}{*}{ Genotype } & \multicolumn{2}{|c|}{ V6-V7 growth stage } & \multicolumn{2}{|c|}{ Pollen Shed } & \multicolumn{2}{|c|}{ Dough } & \multicolumn{2}{|c|}{ Harvest } & \multicolumn{2}{|c|}{ Senescence } \\
\hline & & Mean & $\mathbf{S E}^{5}$ & Mean & $\mathrm{SE}^{5}$ & Mean & $\mathrm{SE}^{5}$ & Mean & $\mathbf{S E}^{5}$ & Mean & $\mathrm{SE}^{5}$ \\
\hline \multirow[t]{3}{*}{ Leaf } & Inbred $^{2}$ & 33.6 & 7.12 & 88.1 & 19.7 & NA & NA & 240.4 & 52.22 & NA & NA \\
\hline & Het. $^{3}$ & 27.4 & 6.5 & 24.6 & 1.94 & NA & NA & 324.6 & 44.14 & NA & NA \\
\hline & Hybrid $^{4}$ & 44.6 & 5.66 & 45.8 & 9.65 & NA & NA & 626.8 & 141.62 & NA & NA \\
\hline \multirow[t]{3}{*}{ Stalk } & Inbred $^{2}$ & NA & NA & 5.7 & 0.84 & NA & NA & 36.7 & 13.88 & NA & NA \\
\hline & Het. $^{3}$ & NA & NA & BLD7 & BLD & NA & NA & 12.1 & 2.18 & NA & NA \\
\hline & Hybrid $^{4}$ & NA & NA & BLD & BLD & NA & NA & 34.2 & 7.48 & NA & NA \\
\hline \multirow[t]{3}{*}{ Root Ball } & Inbred $^{2}$ & 7.0 & 1.75 & 11.1 & 1.78 & NA & NA & 10.8 & 1.87 & NA & NA \\
\hline & Het. $^{3}$ & 5.1 & 0.97 & 8.2 & 2.31 & NA & NA & 10.7 & 1.51 & NA & NA \\
\hline & Hybrid $^{4}$ & 11.9 & 1.72 & 10.2 & 2.92 & NA & NA & 23.1 & 3.12 & NA & NA \\
\hline \multirow[t]{3}{*}{ Kernel $^{6}$} & Inbred $^{2}$ & NA & NA & NA & NA & NA & NA & $42.8^{6}$ & 16.60 & NA & NA \\
\hline & Het. $^{3}$ & NA & NA & NA & NA & NA & NA & $37.1^{6}$ & $3.97^{6}$ & NA & NA \\
\hline & Hybrid $^{4}$ & NA & NA & NA & NA & NA & NA & $36.0^{6}$ & $8.14^{6}$ & NA & NA \\
\hline \multirow[t]{3}{*}{ Silk } & Inbred $^{2}$ & NA & NA & BLD & BLD & NA & NA & NA & NA & NA & NA \\
\hline & Het. $^{3}$ & NA & NA & 14.1 & 1.37 & NA & NA & NA & NA & NA & NA \\
\hline & Hybrid $^{4}$ & NA & NA & BLD & BLD & NA & NA & NA & NA & NA & NA \\
\hline \multirow[t]{3}{*}{ Pollen } & Inbred $^{2}$ & NA & NA & BLD & BLD & NA & NA & NA & NA & NA & NA \\
\hline & Het. $^{3}$ & NA & NA & BLD & BLD & NA & NA & NA & NA & NA & NA \\
\hline & Hybrid $^{4}$ & NA & NA & BLD & BLD & NA & NA & NA & NA & NA & NA \\
\hline \multirow[t]{3}{*}{ Whole Plant } & Inbred $^{2}$ & NA & NA & 27.6 & 9 & NA & NA & NA & NA & $124.2^{6}$ & $16.47^{6}$ \\
\hline & Het. $^{3}$ & NA & NA & 6.7 & 1.02 & NA & NA & NA & NA & $41.2^{6}$ & $6.42^{6}$ \\
\hline & Hybrid $^{4}$ & NA & NA & 14.1 & 2.82 & NA & NA & NA & NA & $69.9^{6}$ & $17.76^{6}$ \\
\hline \multirow{3}{*}{$\begin{array}{l}\text { Whole Plant no } \\
\text { Root Ball }\end{array}$} & Inbred $^{2}$ & NA & NA & NA & NA & 97.2 & 10.66 & NA & NA & NA & NA \\
\hline & Het. $^{3}$ & NA & NA & NA & NA & 19.4 & 3.25 & NA & NA & NA & NA \\
\hline & Hybrid $^{4}$ & NA & NA & NA & NA & 59.5 & 18.18 & $\mathrm{NA}$ & NA & NA & NA \\
\hline
\end{tabular}

${ }^{1}$ Data are shown in $\mathrm{ng} / \mathrm{g}$ fresh weight unless noted otherwise.

${ }^{2}$ Inbred ( $2 / 3$ alleles of Cry $\left.1 \mathrm{Ac}\right)$.

${ }^{3}$ Commercial hybrid (Heterozygous for Cry1Ac).

${ }^{4}$ Hybrid (Homozygous for Cry1 Ac).

${ }^{5}$ Standard error.

${ }^{6} \mathrm{ng} / \mathrm{g}$ dry weight.

${ }^{7} \mathrm{BLD}=$ below limit of detection (51.6 ng/g dry weight).

${ }^{8} \mathrm{NA}=$ not available. 
A review of the environmental safety of the Cry 1 Ac protein

Table I.2. Expression of Cry1Ac in Gossypium hirsutum event MON-00531-6 (USDA APHIS, 1994) ${ }^{1}$.

\begin{tabular}{|c|c|c|c|c|c|c|}
\hline \multirow[t]{2}{*}{ Tissue } & \multicolumn{2}{|c|}{1992} & \multicolumn{2}{|c|}{1993} & \multicolumn{2}{|c|}{1999} \\
\hline & Mean & Range & Mean & Range & Mean & $\mathbf{S D}^{2}$ \\
\hline Young Leaf & 1.56 & $1.10-2.04$ & 2.59 & $0.41-5.91$ & 5.00 & 1.84 \\
\hline Leaf June & 1.40 & $\mathrm{NA}^{3}$ & 5.12 & NA & NA & NA \\
\hline Leaf July & 1.49 & NA & 3.21 & NA & NA & $\mathrm{NA}$ \\
\hline Leaf August & 3.55 & NA & 0.13 & NA & NA & NA \\
\hline Leaf September & 1.3 & NA & 0.23 & NA & NA & NA \\
\hline Seed & 0.86 & $0.49-1.62$ & 2.18 & $1.13-3.41$ & 4.30 & 0.86 \\
\hline Pollen & $11.5 \mathrm{ng} / \mathrm{g}$ & NA & NA & NA & NA & NA \\
\hline Nectar & $\mathrm{BLD}^{4}$ & NA & NA & NA & NA & $\mathrm{NA}$ \\
\hline Whole Plant & 0.044 & NA & NA & NA & NA & $\mathrm{NA}$ \\
\hline
\end{tabular}

${ }^{1}$ Data reported in $\mu \mathrm{g} / \mathrm{g}$ fresh weight unless noted otherwise.

${ }^{2}$ Standard deviation.

${ }^{3} \mathrm{NA}=$ not available.

${ }^{4} \mathrm{BLD}=$ below limit of detection $(1.6 \mathrm{ng} / \mathrm{g})$.

Table I.3. Expression of Cry1Ac in Gossypium hirsutum event MON-00531-6 (CTNBio, 2005)1.

\begin{tabular}{|l|c|}
\hline Tissue & Mean \\
\hline Leaves-20 days after planting & 2.93 \\
\hline Leaves-130 days after planting & 3.02 \\
\hline Seeds & 6.88 \\
\hline
\end{tabular}

${ }^{1}$ Data from field trials in Brazil and values are $\mu \mathrm{g} / \mathrm{g}$ fresh weight.

Table I.4. Expression of Cry1Ac in Gossypium hirsutum event MON-00531-6 (OGTR, 2002)1.

\begin{tabular}{|l|c|c|c|c|}
\hline \multirow{2}{*}{ Tissue } & \multicolumn{2}{|c|}{ 1998 } & \multicolumn{2}{|c|}{ M99 } \\
\cline { 2 - 5 } & Mean & STD & 2.05 & 0.71 \\
\hline Leaf & 1.95 & 1.21 & 2.64 & 0.63 \\
\hline Seed & 3.22 & 0.77 & $<0.07$ & NA $^{2}$ \\
\hline Whole Plant & 0.13 & 0.04 & 0.01 & $<0.01$ \\
\hline
\end{tabular}

${ }^{1}$ Data are reported in $\mu \mathrm{g} / \mathrm{g}$ fresh weight (this data comes from the regulatory submission for event 15985 ).

${ }^{2} \mathrm{NA}=$ not available.

Table I.5. Expression of Cry1Ac in Gossypium hirsutum event MON-15985-7 (OGTR, 2002)1.

\begin{tabular}{|l|c|c|c|c|}
\hline \multirow{2}{*}{ Tissue } & \multicolumn{2}{|c|}{$\mathbf{1 9 9 8}$} & \multicolumn{2}{|c|}{ M99 } \\
\cline { 2 - 5 } & Mean & SD $^{2}$ & 2.07 & 0.61 \\
\hline Leaf & 2.75 & 1.32 & 2.6 & 0.66 \\
\hline Seed & 3.35 & 0.63 & 0.08 & 0.01 \\
\hline Pollen & 0.17 & 0.08 & 0.05 & 0.07 \\
\hline
\end{tabular}

${ }^{1}$ MON-15985-7 is a re-transformation of MON-00531-6 with an additional Cry protein. This data can be considered additional information for event MON-00531-6. Data are reported as $\mu \mathrm{g} / \mathrm{g}$ fresh weight.

${ }^{2} \mathrm{SD}=$ standard deviation. 
Table I.6. Expression of Cry1Ac in Gossypium hirsutum event DAS 21023 (USDA APHIS, 2003) ${ }^{1}$.

\begin{tabular}{|l|c|c|}
\hline Tissue & Mean & Range \\
\hline Young Leaf (3-6 week) & 1.92 & $0.46-3.5$ \\
\hline Terminal Leaf & 1.44 & $0.24-2.4$ \\
\hline Flower & 1.92 & $1.3-2.4$ \\
\hline Square & 1.84 & $0.46-1.1$ \\
\hline Boll (early) & 0.77 & $0.8-2.2$ \\
\hline Whole Plant (seedling) & 1.59 & $0.57-2.1$ \\
\hline Whole Plant (pollination) & 1.15 & $0.31-1.3$ \\
\hline Whole Plant (defoliation) & 0.81 & $0.09^{2}-0.44$ \\
\hline Root (seedling) & 0.20 & ND-0.23 \\
\hline Root (pollination) & 0.10 & ND-0.11 \\
\hline Root (defoliation) & 0.05 & $0.9-2.4$ \\
\hline Pollen & 1.44 & $0.33^{2}-0.78$ \\
\hline Seed & 0.57 & \\
\hline
\end{tabular}

${ }^{1}$ Values are expressed in $\mu \mathrm{g} / \mathrm{g}$ dry weight unless otherwise noted.

${ }^{2}$ Below the limit of quantification for the method ( 0.001 to $0.375 \mathrm{ng} / \mathrm{mg}$ depending on the matrix).

${ }^{3}$ Values are $\mu \mathrm{g} / \mathrm{g}$ fresh weight.

Table I.7. Expression of Cry1Ac in expression of Cry1Ac in Gossypium hirsutum event DAS-21023-5 X DAS-24236-5 (FSANZ, 2004)1.

\begin{tabular}{|c|c|}
\hline Tissue & Mean \\
\hline Young Leaf (3-6 week) & 1.82 \\
\hline Terminal Leaf & 1.31 \\
\hline Flower & 1.83 \\
\hline Square & 1.82 \\
\hline Boll (early) & 0.64 \\
\hline Whole plant (seedling) & 1.37 \\
\hline Whole plant (pollination) & 1.05 \\
\hline Whole plant (defoliation) & 0.6 \\
\hline Root (seedling) & 0.17 \\
\hline Root (pollination) & $0.07^{2}$ \\
\hline Root (defoliation) & ND \\
\hline Pollen $^{3}$ & 1.45 \\
\hline Seed $^{3}$ & 0.55 \\
\hline
\end{tabular}

Table I.8. Expression of Cry1Ac in Gossypium hirsutum event 31807/31808 (FDA, 2007).

\begin{tabular}{|l|l|}
\hline Tissue & Maximum Expression \\
\hline Seed & $2.5 \mathrm{ppm}^{1}$ \\
\hline
\end{tabular}

${ }^{1}$ Equivalent to $2.5 \mu \mathrm{g} / \mathrm{g}$ fresh weight.

\section{ANNEX II: SUMMARY OF PHENOTYPIC ANALYSES OF GE PLANTS EXPRESSING CRY1AC}

The tables that follow present summary data from peer-reviewed publications and regulatory submissions.
The data is presented in the format in which it is available in the cited document in order to facilitate crossreferencing. Additional information on collection and sampling methodologies can be found in the referenced sources. 
A review of the environmental safety of the Cry1Ac protein

Table II.1. Summary of phenotypic analysis of event MON-00531-6 (USDA APHIS, 1996) ${ }^{1}$.

\begin{tabular}{|c|c|c|}
\hline Phenotypic Characteristic & Reported Result & Observations of differences \\
\hline Weediness & No significant differences ${ }^{2}$ & \\
\hline Emergence & No significant differences ${ }^{2}$ & Increased emergence at one location \\
\hline Seedling Vigor & No significant differences ${ }^{2}$ & Increased vigor at one location \\
\hline Dormancy & No significant differences ${ }^{2}$ & $\begin{array}{l}\text { Some dormancy at one location reportedly due to greenhouse } \\
\text { produced seed }\end{array}$ \\
\hline Germination & No significant differences ${ }^{2}$ & \\
\hline Morphology & No significant differences ${ }^{2}$ & \\
\hline Time to Flowering & No significant differences ${ }^{2}$ & \\
\hline Fruiting & No significant differences ${ }^{2}$ & \\
\hline Boll Formation & No significant differences ${ }^{2}$ & \\
\hline Boll Development & No significant differences ${ }^{2}$ & \\
\hline Yield & No significant differences ${ }^{2}$ & \\
\hline Disease Susceptibility & No significant differences ${ }^{2}$ & \\
\hline Volunteerism & No significant differences ${ }^{2}$ & \\
\hline
\end{tabular}

${ }^{1}$ Summarized from descriptive text in USDA APHIS (1996).

${ }^{2}$ Significant here does not refer to statistical significance. Information on statistical analysis is not provided.

Table II.2. Summary of mean emergence, flowering, and harvest dates for event MON-15985-7 and MON-00531-6 (USDA APHIS, 2000) ${ }^{1}$.

\begin{tabular}{|l|c|c|c|c|c|c|}
\hline Site & Event or Line \# & $\begin{array}{c}\text { Percent Seedlings } \\
\text { Emerged (7 days) }\end{array}$ & $\begin{array}{c}\text { Percent Seedlings } \\
\text { Emerged (14 } \\
\text { days) }\end{array}$ & $\begin{array}{c}\text { First White Flow- } \\
\text { er Observed }\end{array}$ & $\begin{array}{c}\text { Date of First } \\
\text { Cracked Boll } \\
\text { Counts }\end{array}$ & $\begin{array}{c}\text { Harvest Date } \\
\text { Arizona 1 }\end{array}$ \\
& 15985 & 71 & 82 & $7 / 21 / 1998$ & $9 / 8 / 1998$ & $10 / 16 / 1998$ \\
& DP50B & 80 & 75 & $7 / 21 / 1998$ & $9 / 8 / 1998$ & $10 / 16 / 1998$ \\
& DP50 & 70 & 73 & $7 / 21 / 1998$ & $9 / 8 / 1998$ & $10 / 16 / 1998$ \\
\hline Arizona 2 & 15985 & 51 & 72 & $7 / 27 / 1998$ & $9 / 8 / 1998$ & $11 / 18 / 1998$ \\
& DP50B & 70 & 76 & $7 / 23 / 1998$ & $9 / 8 / 1998$ & $11 / 18 / 1998$ \\
& DP50 & 49 & 62 & $7 / 23 / 1998$ & $9 / 8 / 1998$ & $11 / 18 / 1998$ \\
\hline Louisiana 1 & 15985 & 52 & 68 & $8 / 2 / 1998$ & $9 / 21 / 1998$ & $10 / 27 / 1998$ \\
& DP50B & 48 & 56 & $7 / 31 / 1998$ & $9 / 21 / 1998$ & $10 / 27 / 1998$ \\
& DP50 & 48 & 67 & $7 / 31 / 1998$ & $9 / 21 / 1998$ & $10 / 27 / 1998$ \\
\hline Louisiana 2 & 15985 & 73 & 82 & $7 / 20 / 1998$ & $8 / 31 / 1998$ & $10 / 14 / 1998$ \\
& DP50B & 68 & 71 & $7 / 20 / 1998$ & $8 / 31 / 1998$ & $10 / 14 / 1998$ \\
& DP50 & 54 & 56 & $7 / 20 / 1998$ & $8 / 31 / 1998$ & $10 / 14 / 1998$ \\
\hline Mississippi 1 & 15985 & 70 & 75 & $7 / 30 / 1998$ & $9 / 4 / 1998$ & $10 / 19 / 1998$ \\
& DP50B & 75 & 76 & $7 / 30 / 1998$ & $9 / 4 / 1998$ & $10 / 19 / 1998$ \\
& DP50 & 78 & 62 & $7 / 30 / 1998$ & $9 / 4 / 1998$ & $10 / 19 / 1998$ \\
\hline Mississippi 2 & 15985 & 63 & 78 & $7 / 20 / 1998$ & $9 / 8 / 1998$ & $10 / 5 / 1998$ \\
& DP50B & 76 & 73 & $7 / 20 / 1998$ & $9 / 8 / 1998$ & $10 / 5 / 1998$ \\
& DP50 & 74 & 69 & $7 / 20 / 1998$ & $9 / 8 / 1998$ & $10 / 5 / 1998$ \\
\hline South Carolina & 15985 & 88 & 94 & $7 / 23 / 1998$ & $9 / 9 / 1998$ & $10 / 27 / 1998$ \\
& DP50B & 77 & 87 & $7 / 23 / 1998$ & $9 / 9 / 1998$ & $10 / 27 / 1998$ \\
& DP50 & 60 & 78 & $7 / 23 / 1998$ & $9 / 9 / 1998$ & $10 / 27 / 1998$ \\
\hline Texas ${ }^{3}$ & 15985 & 73 & 93 & $7 / 23 / 1998$ & $9 / 2 / 1998$ & $9 / 28 / 1998$ \\
& DP50B & 83 & 83 & $7 / 20 / 1998$ & $9 / 2 / 1998$ & $9 / 28 / 1998$ \\
& DP50 & 64 & 69 & $7 / 23 / 1998$ & $9 / 2 / 1998$ & $10 / 9 / 1998$ \\
\hline
\end{tabular}

${ }^{1}$ USDA APHIS 2000 is a regulatory submission for MON-15985-7 which contains information about MON-00531-6 as a GE parental control.

${ }^{2} \mathrm{DP} 50 \mathrm{~B}=$ the transgenic parent of 15985 (event 531).

${ }^{3} \mathrm{DP} 50=$ the non-transgenic parent of DP50.

${ }^{4}$ Harvest dates at the Texas site were different due to excessive moisture which would have increased boll rot. 
Table II.3. Summary of mean height:node ration, days to peak bloom and total cracked boll counts for event MON-15985-7, and MON-00531-6 (USDA APHIS, 2000).

\begin{tabular}{|l|c|c|c|}
\hline Event or Line \# & Height:Node Ration & Mean Days to Peak Bloom & Mean Total Number of Cracked Bolls / plot \\
\hline 15985 & 1.70 & 15.29 & 407 \\
\hline DP50B $^{2}$ & 1.77 & 15.03 & 431 \\
\hline DP50 & 1.72 & 15.77 & 284 \\
\hline
\end{tabular}

${ }^{1}$ USDA APHIS (2000) is a regulatory submission for MON-15985-7 which contains information about MON-00531-6 as a GE parental control.

${ }^{2} \mathrm{DP} 50 \mathrm{~B}=$ the transgenic parent of 15985.

${ }^{3} \mathrm{DP} 50=$ the non-transgenic parent of DP50.

Table II.4. Germination and seedling vigor tests on seed from two locations for MON-15985-7 (USDA APHIS, 2000) ${ }^{1}$.

\begin{tabular}{|l|c|c|c|}
\hline Event or Line \# & \% Germination Day 4 & \% Germination Day 9 & \% Cool Germination at 18 $\mathbf{C}^{\circ}$ Day 7 \\
\hline $15985^{2}$ & 76 & 77 & 72 \\
\hline DP50B $^{3}$ & 83 & 83 & 80 \\
\hline DP50 & 88 & 89 & 82 \\
\hline
\end{tabular}

${ }^{1}$ USDA APHIS (2000) is a regulatory submission for MON-15985-7 which contains information about MON-00531-6 as a GE parental control.

${ }^{2} 15985=$ MON-15985-7.

${ }^{3} \mathrm{DP} 50 \mathrm{~B}=$ the transgenic parent of $15985, \mathrm{MON}-00531-6$.

${ }^{4}$ DP50 $=$ the non-transgenic parent of DP50.

Table II.5. Germination and dormancy results from seed harvested in three locations in 1999 for event MON-15985-7 and MON-00531-6 (USDA APHIS, 2000) ${ }^{1}$.

\begin{tabular}{|c|c|c|c|c|c|}
\hline Temperature $\left({ }^{\circ} \mathrm{C}\right)$ & Variety & $\begin{array}{c}\text { Mean pvhs }{ }^{3} \\
\text { (Dormant) }(\%)\end{array}$ & Mean $\operatorname{pgerm}^{4}(\%)$ & Mean pfms ${ }^{5}(\%)$ & Mean pdegen ${ }^{6}(\%)$ \\
\hline 5 & $\begin{array}{c}1598 \\
\text { DP50B }{ }^{2} \\
\text { Ref. Range } \\
\end{array}$ & $\begin{array}{c}1.2 \\
0.0 \\
(0-41) \\
\end{array}$ & $\begin{array}{c}0.0 \\
0.0 \\
(0-1) \\
\end{array}$ & $\begin{array}{c}95.1 \\
95.2 \\
(53-99) \\
\end{array}$ & $\begin{array}{c}4.1 \\
5.4 \\
(1-20) \\
\end{array}$ \\
\hline 10 & $\begin{array}{c}1598 \\
\text { DP50B } \\
\text { Ref. Range }\end{array}$ & $\begin{array}{c}0.0 \\
0.0 \\
(0-28)\end{array}$ & $\begin{array}{c}1.2 \\
1.3 \\
(0-3)\end{array}$ & $\begin{array}{c}73.9^{6} \\
78.5 \\
(38-91)\end{array}$ & $\begin{array}{c}26.4^{6} \\
21.7 \\
(9-62)\end{array}$ \\
\hline 20 & $\begin{array}{c}1598 \\
\text { DP50B } \\
\text { Ref. Range } \\
\end{array}$ & $\begin{array}{c}0.0 \\
0.0 \\
(0-6) \\
\end{array}$ & $\begin{array}{c}95.4 \\
97.4 \\
(74-100) \\
\end{array}$ & $\begin{array}{c}0.0 \\
0.0 \\
(0-13) \\
\end{array}$ & $\begin{array}{c}5.4^{6} \\
3.1 \\
(0-26) \\
\end{array}$ \\
\hline 30 & $\begin{array}{c}1598 \\
\text { DP50B }^{1} \\
\text { Ref. Range } \\
\end{array}$ & $\begin{array}{c}0.0 \\
0.0 \\
(0-0) \\
\end{array}$ & $\begin{array}{c}93.9^{6} \\
98.6 \\
(83-100) \\
\end{array}$ & $\begin{array}{c}0.0 \\
0.0 \\
(0-0) \\
\end{array}$ & $\begin{array}{c}6.6^{6} \\
2.2 \\
(0-17) \\
\end{array}$ \\
\hline 40 & $\begin{array}{c}1598 \\
\text { DP50B }^{1} \\
\text { Ref. Range } \\
\end{array}$ & $\begin{array}{c}0.0 \\
0.0 \\
(0-0) \\
\end{array}$ & $\begin{array}{c}85.9 \\
89.3 \\
(70-96) \\
\end{array}$ & $\begin{array}{c}0.0 \\
0.0 \\
(0-0) \\
\end{array}$ & $\begin{array}{c}14.9 \\
11.1 \\
(4-30) \\
\end{array}$ \\
\hline $5 / 20$ & $\begin{array}{c}1598 \\
\text { DP50B }^{1} \\
\text { Ref. Range } \\
\end{array}$ & $\begin{array}{c}0.0 \\
0.1 \\
(0-29) \\
\end{array}$ & $\begin{array}{l}\mathrm{NC}^{7} \\
\mathrm{NC}^{7} \\
\mathrm{NC}^{7} \\
\end{array}$ & $\begin{array}{l}\mathrm{NC}^{7} \\
\mathrm{NC}^{7} \\
\mathrm{NC}^{7} \\
\end{array}$ & $\begin{array}{l}\mathrm{NC}^{7} \\
\mathrm{NC}^{7} \\
\mathrm{NC}^{7} \\
\end{array}$ \\
\hline $10 / 20$ & $\begin{array}{c}1598 \\
\text { DP50B }^{1} \\
\text { Ref. Range } \\
\end{array}$ & $\begin{array}{c}0.0 \\
0.0 \\
(0-18) \\
\end{array}$ & $\begin{array}{l}\mathrm{NC}^{7} \\
\mathrm{NC}^{7} \\
\mathrm{NC}^{7} \\
\end{array}$ & $\begin{array}{c}1.9 \\
1.2 \\
(0-79) \\
\end{array}$ & $\begin{array}{c}7.5 \\
5.8 \\
(1-31) \\
\end{array}$ \\
\hline $20 / 30$ & $\begin{array}{c}1598 \\
\text { DP50B } \\
\text { Ref. Range }\end{array}$ & $\begin{array}{c}0.0 \\
0.0 \\
(0-2)\end{array}$ & $\begin{array}{l}\mathrm{NC}^{7} \\
\mathrm{NC}^{7} \\
\mathrm{NC}^{7}\end{array}$ & $\begin{array}{c}0.0 \\
0.0 \\
(0-1)\end{array}$ & $\begin{array}{c}5.1 \\
3.7 \\
(0-17)\end{array}$ \\
\hline
\end{tabular}

${ }^{1}$ USDA APHIS (2000) is a regulatory submission for MON-15985-7 which contains information about MON-00531-6 as a GE parental control.

${ }^{2} \mathrm{DP} 50 \mathrm{~B}=$ The transgenic parent of 15985, MON-00531-6.

${ }^{3}$ pvhs $=$ percent viable hard seed.

${ }^{4}$ pgerm $=$ percent germinated seed.

$5 \mathrm{pfms}=$ percent viable firm-swollen seed.

${ }^{6}$ pdegen $=$ percent degenerated seed.

${ }^{7}$ Indicates a significant difference from DP50B at $\mathrm{P} \leq 0.05$.

${ }^{8} \mathrm{NC}=$ no comparison of combined means possible due to significant variety by site interaction at $\mathrm{P} \leq 0.05$.

Additional anecdotal reports: disease susceptibility in MON-15985-7 is reported similar to control. 
A review of the environmental safety of the Cry1Ac protein

Table II.6. Agronomic characteristics of event DAS-21023-5 lines expressing Cry1Ac protein in comparison to parent variety PSC355 (USDA APHIS, 2003).

\begin{tabular}{|c|c|c|c|c|}
\hline Variable & Units & $\begin{array}{c}\text { 3006-210-3 } \\
\text { (Cry1Ac) }\end{array}$ & PSC355 (Null) & $\begin{array}{c}\text { Number } \\
\text { of Locations }\end{array}$ \\
\hline \multicolumn{5}{|l|}{ Growth Habit } \\
\hline Plant Height & Inches & 39.9 & 41.5 & 17 \\
\hline Total Nodes & Number per plant & 17.4 & 17.6 & 16 \\
\hline Hieght:Node Ratio & Inches per plant & 2.29 & 2.35 & 17 \\
\hline Node of the 1st Fruiting Branch & Node & 6.7 & 6.6 & 17 \\
\hline Fruiting Branches & Number per plant & 11.7 & 12.1 & 16 \\
\hline Total Fruiting Position & Number per plant & 25.6 & 26.6 & 17 \\
\hline Vegetative Bolts & Number per plant & 2.3 & 1.6 & 16 \\
\hline \multicolumn{5}{|l|}{ Germination and Emergence } \\
\hline Field Emergence & $\%$ & 63.6 & 82.3 & 19 \\
\hline Cool Vigor & $\%$ & 32 & 38 & 20 \\
\hline 4 Day Warm & $\%$ & 64 & 65 & 20 \\
\hline 7 Day Warm & $\%$ & 80 & 82 & 20 \\
\hline Total Germination & $\%$ & 85 & 87 & 20 \\
\hline Dormant Seed & $\%$ & 0.6 & 0.3 & 20 \\
\hline \multicolumn{5}{|l|}{ Vegetative Vigor } \\
\hline Vegetative branches & Number per plant & 2.9 & 2.6 & 16 \\
\hline \multicolumn{5}{|l|}{ Flowering Period } \\
\hline Days to First Flower & Days & 61.9 & 60.6 & 18 \\
\hline Node of White Flower - 15 days & Node & 12.9 & 12.9 & 17 \\
\hline Node of White Flower - 30 days & Node & 17.0 & 16.8 & 15 \\
\hline \multicolumn{5}{|l|}{ Reproductive Potential } \\
\hline Percent Retention - total & $\%$ & 49.0 & 44.4 & 16 \\
\hline Percent Retention - 1st position & $\%$ & 58.5 & 54.3 & 16 \\
\hline Percent Open Bolls & $\%$ per plant & 73.5 & 75.4 & 17 \\
\hline Seed Cotton Weight per Boll & Grams per boll & 5.5 & 5.1 & 19 \\
\hline Lint Percent & $\%$ & 37.9 & 37.3 & 19 \\
\hline Seed Index (fuzzy) & Grams per 100 seeds & 11.0 & 10.7 & 17 \\
\hline Lint per Acre & Pounds per acre & 1005 & 993 & 17 \\
\hline \multicolumn{5}{|l|}{ Fiber Quality } \\
\hline Length & Inches & 1.160 & 1.147 & 19 \\
\hline Strength & Grams per tex & 31.9 & 32.6 & 19 \\
\hline Micronaire & Micronaire units & 4.51 & 4.96 & 19 \\
\hline Length Uniformity & $\%$ & 85.8 & 85.7 & 19 \\
\hline Reflectance & $\%$ & 76.0 & 74.6 & 19 \\
\hline Yellowness & Hunter's $+b$ scale & 8.3 & 8.4 & 19 \\
\hline
\end{tabular}

Additional anecdotal reports: disease susceptibility (no difference). 
Table II.7. Examples of field performance characteristics of events 31807 and 31808 compared to a commercial variety used as a control (USDA APHIS, 1997c).

\begin{tabular}{|l|c|c|c|}
\hline Evaluation parameter & Control (e.g. Coker 130) & Event 31807 & Event 31808 \\
\hline $\begin{array}{l}\text { \% Fruit Damaged by Helicoverpa zea (\% transformed to square } \\
\text { root of their arcsine) }\end{array}$ & 12.87 & 1.88 & 0.61 \\
\hline Squares Damaged by Heliothis zea & 15.4 & 2.92 & 2.92 \\
\hline Crown Gall Incidence & 0 & 0 & 0 \\
\hline Cauliflower Mosaic Virus Infection & 0 & Nithin expected range & Within expected range \\
\hline $\begin{array}{l}\text { Susceptibility to Phomopsis, Verticillium and other normal fungal } \\
\text { pathogens of cotton }\end{array}$ & Within expected range & Withe & Within expected range \\
\hline $\begin{array}{l}\text { Levels of non-target insect pests such as cotton aphid, tarnished } \\
\text { plant bug, spider mite, and boll weevil }\end{array}$ & Within expected range & Within expected range & Yes \\
\hline Bromoxynil tolerance & No & Yes & normal \\
\hline Seed Germination & normal & normal & normal \\
\hline Plant Morphology & normal & normal & normal \\
\hline Flowering Period & normal & normal & normal \\
\hline Yield & normal & normal & normal \\
\hline Fiber Quality & 0 & 0 & 0 \\
\hline Incidence of post-season volunteer cotton plants & & \\
\hline
\end{tabular}

Table II.8. Mean comparisons of germination percentages for event 31807 (USDA APHIS, 1997c).

\begin{tabular}{|l|c|c|c|}
\hline Event or Strain & N & Warm Germination Percentage & Cool Germination Percentage \\
\hline $31707^{1}$ & 4 & 99 & 92 \\
\hline $31803^{1}$ & 4 & 98 & 86 \\
\hline $31807 \mathrm{~A}$ & 3 & 97 & 87 \\
\hline 31807 C & 4 & 97 & 89 \\
\hline Coker $130^{2}$ & 4 & 97 & 92 \\
\hline ST474 ${ }^{2}$ & 4 & 95 & 88 \\
\hline LSD $(0.05)$ & & 2 & 5 \\
\hline CV $(\%)$ & & 1.6 & 3.5 \\
\hline
\end{tabular}

${ }^{1}$ GE plants expressing Cry1Ac.

${ }^{2}$ Untransformed varieties. 
Table II.9. Agronomic performance of DBT418-converted hybrid (event DK-B89614-9) as compared to the conventional version of the same hybrid (USDA APHIS, 1996) ${ }^{1}$.

\begin{tabular}{|l|c|c|}
\hline Trait & Counterpart Unconverted Hybrid & DBT418 \\
\hline Yield (bushels/acre) & 130.4 & 129.5 \\
\hline Grain Moisture (\%) & 13.9 & $55.3^{2}$ \\
\hline Test Weight (lbs.) & 55.0 & 61.1 \\
\hline Final Stand Count & 61.2 & $8.2^{1}$ \\
\hline Seedling Vigor (1-9 scale) & 6.5 & 41.0 \\
\hline Plant Height (in.) & 89.2 & 1342 \\
\hline Ear Height (in.) & 42.5 & $1342^{1}$ \\
\hline Pollen GDU & 1339 & $4.3^{1}$ \\
\hline Silk GDU & 1335 & $4.9^{1}$ \\
\hline Stay-Green (1-9 scale) & 4.2 & 0.04 \\
\hline Intactness (1-9 scale) & 4.1 & 2.9 \\
\hline Dropped Ears (\%) & 0.04 & 5.0 \\
\hline Stalk Lodged (\%) & 3.1 & 5.1 \\
\hline Root Lodged (\%) & 2.9 & 3.4 \\
\hline Barren Plants (\%) & & \\
\hline
\end{tabular}

${ }^{1}$ Additional anecdotal reports: disease susceptibility (no different).

${ }^{2}$ Statistically different from the control at the $\mathrm{P}=0.5$ level.

\section{ANNEX III: SUMMARY OF COMPOSITIONAL ANALYSES OF GE PLANTS EXPRESSING CRY1AC}

The tables that follow present summary data from peer-reviewed publications and regulatory submissions.
The data is presented in the format in which it is available in the cited document in order to facilitate crossreferencing. Additional information on collection and sampling methodologies can be found in the referenced sources.

Table III.1. Proximate analysis of grain from Zea mays event DBT418 (ANZFA, 2002)1.

\begin{tabular}{|l|c|c|c|c|c|}
\hline \multirow{2}{*}{ Constituent Analyzed } & \multicolumn{2}{|c|}{ DBT418 $^{2}$} & \multicolumn{2}{|c|}{ Control $^{2}$} & \multirow{2}{*}{ Literature Range $^{2}$} \\
\cline { 2 - 5 } & Mean & Standard Deviation & Mean & Standard Deviation & \\
\hline Protein & 9.02 & 0.22 & 8.56 & 0.16 & $6.0-12.0$ \\
\hline Oil & 4.05 & 0.05 & 3.92 & 0.04 & $3.1-5.7$ \\
\hline Fibre & 1.96 & 0.03 & 2.02 & 0.03 & $2.0-5.5$ \\
\hline Ash & 1.32 & 0.01 & 1.30 & 0.02 & $1.1-3.9$ \\
\hline Moisture & 8.14 & 0.04 & 8.22 & 0.04 & $7-23$ \\
\hline
\end{tabular}

${ }^{1}$ Values are \% dry weight.

${ }^{2}$ Sample size $=30$. 
Table III.2. Proximate analysis of forage from Zea mays event DBT418 (ANZFA, 2002)1.

\begin{tabular}{|l|c|c|c|c|c|}
\hline \multirow{2}{*}{ Constituent Analyzed } & \multicolumn{2}{|c|}{ DBT418 $^{\mathbf{2}}$} & \multicolumn{2}{c|}{ Control $^{\mathbf{3}}$} & \multirow{2}{*}{ Literature Range $^{*}$} \\
\cline { 2 - 6 } & Mean & Standard Deviation & Mean & Standard Deviation & \\
\hline Protein & 6.81 & 0.23 & 7.12 & 0.29 & $3.5-15.9$ \\
\hline Oil & 2.77 & 0.07 & 2.82 & 0.06 & $0.7-6.7$ \\
\hline Fibre & 20.56 & 0.03 & 20.57 & 0.38 & $2.0-5.5$ \\
\hline Ash & 4.33 & 0.15 & 4.28 & 0.13 & $1.3-10.5$ \\
\hline Moisture & 66.68 & 0.04 & 66.96 & 0.04 & NA \\
\hline
\end{tabular}

${ }^{1}$ Values are $\%$ dry weight.

${ }^{2}$ Sample size $=24$.

${ }^{3}$ Sample size $=30$.

Table III.3. Proximate analysis of seed from Gossypium hirsutum event MON-00531-6 (Berberich et al.1996) ${ }^{1}$.

\begin{tabular}{|l|c|c|c|c|c|}
\hline \multirow{2}{*}{ Characteristic } & \multicolumn{2}{|c|}{ Coker 312 } & \multicolumn{2}{c|}{ MON-00531-6 } & \multirow{2}{*}{ Literature Range } \\
\cline { 2 - 6 } & Mean & Range & Mean & $22.8-31.0$ & $12-32$ \\
\hline Protein & 27.00 & $23.3-28.4$ & 27.56 & 22.2 & $16.1-26.7$ \\
\hline Fat & 22.95 & $19.6-25.1$ & 23.23 & $3.9-4.7$ & $4.1-4.9$ \\
\hline Ash & 4.63 & $4.3-5.0$ & 4.53 & $42.0-46.7$ & NA $^{2}$ \\
\hline Carbohydrate & 45.40 & $42.8-47.6$ & 44.68 & $495-511$ & NA \\
\hline Calories/100g & 496.32 & $479-508$ & 498.11 & $11.2-14.7$ & $5.4-10.1$ \\
\hline Moisture & 12.36 & $9.6-15.9$ & 13.43 & & \\
\hline
\end{tabular}

${ }^{1}$ All values are $\%$ dry weight except moisture (\% fresh weight) and calories/100g.

${ }^{2} \mathrm{NA}=$ not available.

Table III.4. Proximate analysis of seed from Gossypium hirsutum event MON-15985-7 (USDA APHIS, 2000) ${ }^{1}$.

\begin{tabular}{|c|c|c|c|c|c|c|c|}
\hline \multirow[t]{2}{*}{ Component } & \multicolumn{2}{|c|}{ Event 15985} & \multicolumn{2}{|c|}{ DP50B (event 531) } & \multicolumn{2}{|c|}{ DP50 (non transgenic) } & \multirow{2}{*}{$\begin{array}{l}\text { Commercial } \\
\text { reference } \\
\text { range }\end{array}$} \\
\hline & Mean & Range & Mean & Range & Mean & Range & \\
\hline Protein \% & 26.13 & $21.45-28.82$ & 26.06 & $21.93-28.15$ & 25.96 & $21.76-27.79$ & $21.76-28.15$ \\
\hline Fat $\%$ & 20.52 & $17.54-27.42$ & 20.37 & $16.04-23.48$ & 19.74 & $15.44-23.64$ & $15.44-23.83$ \\
\hline Ash \% & 4.36 & $3.93-4.81$ & 4.38 & $4.06-4.67$ & 4.34 & $3.76-4.85$ & $3.76-4.85$ \\
\hline Fiber, crude \% & 16.83 & $14.93-17.95$ & 17.17 & $15.42-19.69$ & 17.19 & $15.38-19.31$ & $15.38-20.89$ \\
\hline Carbohydrate \% & 49.09 & $42.97-52.69$ & 49.23 & $46.85-51.93$ & 49.94 & $45.64-52.44$ & $45.64-53.62$ \\
\hline Calories/100g DW & 485.33 & $468.50-520.01$ & 484.45 & $463.09-498.71$ & 481.57 & $457.77-499.84$ & $457.77-500.49$ \\
\hline Moisture \% & 5.99 & $4.34-7.59$ & 6.05 & $4.22-7.28$ & 6.03 & $3.97-7.26$ & $3.97-8.47$ \\
\hline
\end{tabular}

${ }^{1}$ MON-15985-7 is MON-00531-6 re-transformed to express an additional Cry protein. These data can be considered additional information on Cry1Ac event MON-00531-6. No statistically significant differences are reported between 15985 and the DP50B parent line. 
A review of the environmental safety of the Cry1Ac protein

Table III.5. Proximate analysis of seed from Gossypium hirsutum event MON-15985-7 (Hamilton et al., 2004)1.

\begin{tabular}{|l|c|c|c|c|c|}
\hline \multirow{2}{*}{ Component } & \multicolumn{2}{|c|}{ MON 15985 } & \multicolumn{2}{c|}{ DP50 } & Literature Range \\
\cline { 2 - 6 } & Mean & Range & Mean & Range & \\
\hline Ash & 4.28 & $3.85-4.92$ & 4.32 & $3.76-5.23$ & $3.87-5.29$ \\
\hline Calories (Kcal/100 g) & 489.65 & $468.50-520.01$ & 487.11 & $457.77-501.84$ & $471.39-506.95$ \\
\hline Carbohydrates & 47.95 & $42.97-52.69$ & 48.55 & $43.69-52.44$ & $45.28-53.62$ \\
\hline Total Fat & 21.33 & $17.54-27.42$ & 20.85 & $15.44-24.29$ & $17.37-25.16$ \\
\hline Crude Fiber & 16.07 & $13.81-17.95$ & 16.22 & $13.45-19.31$ & $13.85-17.94$ \\
\hline ADF & 25.68 & $21.40-31.95$ & 25.26 & $21.10-34.80$ & $21.10-34.80$ \\
\hline NDF $^{3}$ & 38.75 & $34.90-46.20$ & 38.97 & $34.75-43.13$ & $32.92-45.83$ \\
\hline Moisture & 4.86 & $2.32-7.59$ & 4.88 & $2.91-7.26$ & $2.25-7.49$ \\
\hline Protein & 26.26 & $21.45-28.82$ & 26.12 & $21.76-28.24$ & $24.54-30.83$ \\
\hline
\end{tabular}

${ }^{1}$ MON-15985-7 is MON-00531-6 re-transformed to express an additional Cry protein. This data can be considered additional information on Cry1Ac event MON-00531-6. All values are \% dry weight except moisture which is \% fresh weight. No statistically significant differences reported $(\mathrm{P} \leq 0.05)$.

${ }^{2} \mathrm{ADF}=$ acid detergent fiber.

${ }^{3} \mathrm{NDF}=$ neutral detergent fiber.

Table III.6. Proximate analysis of seed from Gossypium hirsutum event DAS-21023-5 (USDA APHIS, 2003).

\begin{tabular}{|l|c|c|c|}
\hline Proximate (\%) & $\begin{array}{c}\text { Cry1Ac } \\
\text { Seed }\end{array}$ & $\begin{array}{c}\text { Control } \\
\text { Seed }\end{array}$ & $\begin{array}{c}\text { Literature } \\
\text { Values }\end{array}$ \\
\hline Ash & 4.0 & 3.9 & $3.76-4.85^{1}$ \\
\hline Total Fat & 23.3 & 21.9 & $15.4-23.8^{1}$ \\
\hline Moisture & 2.8 & 3.2 & $3.97-8.47^{1}$ \\
\hline Protein & 27.3 & 26.7 & $21.8-28.2^{1}$ \\
\hline Carbohydrates & 42.8 & 44.3 & $45.6-53.6^{1}$ \\
\hline Calories (Kcal/100g) & 490 & 481 & NA \\
\hline Crude Fiber & 15.7 & 17.0 & $15.4-20.9^{1}$ \\
\hline Acid Detergent Fiber & 22.6 & 24.4 & $26^{2}, 37.5^{1}$ \\
\hline Neutral Detergent Fiber & 34.1 & 34.7 & $37^{2}, 52.6^{1}$ \\
\hline
\end{tabular}

${ }^{1}$ Reported from OECD Draft Consensus Document, 2002.

${ }^{2}$ Reported from NCPA, Cottonseed Feed Products Guide.
Table III.7. Nutritional fiber analysis of seed from Gossypium hirsutum event 31807/31808 (USDA APHIS, 1997c) ${ }^{1}$.

\begin{tabular}{|l|c|c|c|}
\hline Event & Crude Fiber & $\mathbf{A D F}^{\mathbf{2}}$ & $\mathbf{N D F}^{\mathbf{3}}$ \\
\hline 31707 & 30.2 & 39.7 & 49.4 \\
\hline 31803 & 31.8 & 36.8 & 45.7 \\
\hline 31807 & 32.1 & 42.1 & 48.8 \\
\hline 31808 & 31.4 & 40.4 & 47.5 \\
\hline 42317 & 31.4 & 41.8 & 48.5 \\
\hline Coker 130 & 31.8 & 38.1 & 46.3 \\
\hline Stv. 474 & 30.4 & 40.4 & 47.6 \\
\hline St. LA887 & 32.5 & 42.4 & 49.0 \\
\hline DPL 51 & 33.8 & 41.4 & 48.6 \\
\hline
\end{tabular}

${ }^{1}$ Expressed as percentage of fuzzy seed by weight.

${ }^{2}$ Acid detergent fiber.

${ }^{3}$ Neutral detergent fiber.

Table III.8. Proximate analysis of cottonseed meal from Gossypium hirsutum event 31807/31808 (USDA APHIS, $1997 \mathrm{c}$ ). ${ }^{1}$

\begin{tabular}{|l|c|c|c|c|}
\hline Event & Moisture & Crude Fat/Oil & Protein & Ash \\
\hline 31707 & 2.98 & 2.53 & 49.52 & 6.82 \\
\hline 31803 & 2.00 & 2.42 & 49.41 & 6.36 \\
\hline 31807 & 1.69 & 2.14 & 53.31 & 7.16 \\
\hline 31808 & 2.38 & 2.27 & 51.02 & 6.55 \\
\hline 42317 & 1.69 & 1.73 & 49.17 & 6.53 \\
\hline Coker 130 & 3.14 & 2.39 & 53.10 & 7.14 \\
\hline Stv. 474 & 2.34 & 2.13 & 44.92 & 6.18 \\
\hline St. LA887 & 3.05 & 2.45 & 46.12 & 6.44 \\
\hline DPL 51 & 2.74 & 3.01 & 45.54 & 6.92 \\
\hline
\end{tabular}

${ }^{1}$ Values are $\%$ by weight. 